\title{
膀胱移行上皮癌の組織的電顥的研究
}

\author{
I. 腫瘍細胞の構造と分化度
}

$\begin{array}{rrrrrr}\text { 札幌鉄道病院中央検査室 } & \text { 布 } & \text { 施 } & \text { 裕 } & \text { 輔 } \\ \text { 国立札幌病院泌尿器科 } & \text { 藤 } & \text { 枝 } & \text { 順 } & \text { 一 } & \text { 郎 } \\ & \text { 大 } & & \text { 室 } & & \text { 博 } \\ \text { 前 - 国立札幙病院泌尿器科 } & \text { 勝 } & \text { 目 } & \text { 三 } & \text { 千 } & \text { 人 }\end{array}$

\section{LIGHT AND ELECTRON MICROSCOPIC STUDIES ON HUMAN BLADDER CACINOMAS}

—Relationship between Structure and Differentiation of Cancer Cells-

Yusuke Fuse

Section of Pathology, Sapporo Hospital of Japanese National Railways, Sapporo, Japan

Junichiro Fujieda, Hiroshi Ohmuro and Michito Katsume

Department of Urology, Sapporo National Hospital, Sapporo, Japan

Biopsied tumor tissues of 23 cases of human bladder carcinomas were histologically and electronmicroscopically investigated. The majority of well-differentiated papillary transitional cell carcinomas (Grade I and II) revealed the surface tumor cells accompanied by large granule, degenerative vacuoles and pseudoadenomatous lumina in their surfaces. The well-differentiated cancer cells showed electronmicroscopically the various cytoplasmic organelles such as mitochodria, tight junction, desmosomes, endoplasmic reticulum Golgi apparatus and lysosomes.

On the other hand, squamous and glandular metaplastic foci, disappearance of surface tumor cells and an increase of dark cells and exfoliation of tumor cells were observed in poor-differentiated cancers (Grade III and IV). The poor-differentiated cancer cells showed eletron-microscopically a decrease of various cytoplasmic organelles, especially tight junction, desmosome and mitochondria, and an increase of free ribosomes and microvillous cytoplasmic protrusions and intercellular spaces.

The quantity of glycogen and cytoplasmic fibrile of tumor cells were seemed not to be proportional to differentiation of cancer. In the squamous metaplastic foci in bladder cancers were electronmicroscopically observed an increase of tonofibrile, desmosome and tonofilament desmosome complex. However, it was unable to identify the presence of typical keratohyalin granules in these foci.

Discussion was also briefly made on the genesis of dark cell, lymphoid reaction in cancer stroma and the direction of tumor growth.

\section{はじめに}

腫瘍の悪性度は細胞の分化度, 成長様式, 浸潤程度な ぞから綜合的に判断されるべきであるが，移行上度癌は 他藏器癌と異なり, 組織的形態から判定される分化度を 付記し，予後を想定する習慣がある.このことは移行上 皮癌では組織学的分化度と生物学的悪性度が他臓器の腫

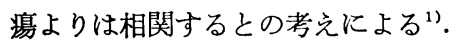

しかし実際には多発する腫瘍がそれぞれ組織学的悪性 度を異にしていたり，同一腫瘍の部位で悪性度が異つて いたり，原発巣と転移巣で組織像が異つていることなど が少なくなく，問題は多い。

笠松ら ${ }^{2)}$ は膀胱癌の生検時と剖検時との対比から移行 に皮癌の組織学的悪性度は固定したものではなく，経時 的により悪性方向に変化することを指摘しているし， 
Jewett $ら^{31}$ は組織形態よりも浸潤度が予後の判定に重要 であるという。

Kretschmer $5^{59}$ は腫湟の組織学的分化度による膀脱 腫瘍の分類は問題が多く，予後の判定に正確な情報を提 供するものではなく，臨床事項を加味した分類の方が実 際的価値があることを強調している．市川，辻 ${ }^{201}$ は腫瘍 の分化度と浸潤度を組合せた悪性度判定法を提唱し採用 している. 生検材料から腫瘍組織形態と分化度を問題に するときには観察範囲が限定されているために生ずる問 題点に留意する必要がある.

Urothelium ${ }^{4}$ ) は単なる保護上皮ではなく，特殊な機

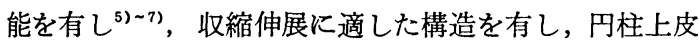
と扁平上皮との中間上皮である．それ故に正常膀胱粘膜 が慢性刺戟によつて比較的容易に扁平上皮あるいは円柱

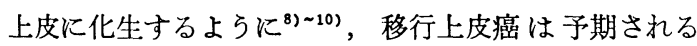
以上にしばしば扁平上皮化生ないし腺化生部分を含むる のである ${ }^{11121}$.

著者らは膀脱移行上皮癌 23 例を組織的電顕的に検索し たので，その結果を報告する.

\section{使用材料と試料作成方法}

膀胖腫瘍材料は国立札幌病院泌尿器科で経尿道的に採 取したもので，その例数は表 1 に示した 23 例である.

生検された腫瘍の小組織片を 2 分し，一半を電顕試料 とし, 他半を光顕試料とした. 電顕試料は速かに $1 \mathrm{~mm}^{3}$ の大きさに細切し， $2 \%$ オスミウム酸・燐酸緩衝溶液 （pH 7.6）にて 2 時間低温固定した. 次いでェタノール 脱水後 epon 812k 包埋重合した. 切片作成には LKB ウルトラミクロトームを使用し, 醋酸ウラニウムと水酸 化鉛の二重染色を施した後, HU-11型電子顕微鏡で検鏡 撮影した. 試料の一部には $5 \%$ グルタールアルデハイド 固定とオスミウム固定の二重固定を行なつた.

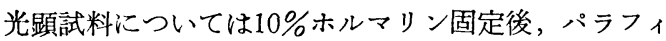
ン切片を作成し，H-E 染色, PAS 染色および鍍銀染色 を行ない，電顕的検索の参考とした。

\section{結果}

\section{組織所見}

今回の検索では生検材料が対象であるために腫瘍の表 面構造に焦点を置き検索した.

充実性癌巣を示す移行上皮癌には種々の間隙形成がみ られるが，間隙は次の 3 種に区別される.すなわち，1） 四 4 に示したような腫瘍細胞の部分的な变性消失によつ て生ずる変性空胞，2）図11に示したような表層腫瘍緑 細の配列の山凸と配列異常によつて生ずる間隙すなわち
偽腺様変化と，3）戝24に示したような真の化生による 腺腔形成などである．偽腺様変化では巨大顆粒を有する 表層腫瘍細胞が間吵を縁取り，变性空胞と区別される. しかし, 变性空胞と偽腺様变化は後述するように腫湯細 胞の脱落を欠く腫瘍にみられる变化であり, 腺上皮化生 と区別しなければならない．

1）腫瑒に接する膀胧粘膜

粘膜上皮は肥厚していることが多い，粘膜の基底層掠 よび中間層では細胞間隙が開いて spongiosis の状態を呈 することが多いが（図 1)，表層細胞は濃縮珄変化を示 し，核に接した空泡を多発する（図 2).表層細胞が有す る空泡性 PAS 陽性粗大顆粒は堿少する.これらの变化 は粘膜固有層の浮腫による.

粘膜の陰窩部分に盲端に終る腺化生をみることがある が（図 3 ）, 扇平上皮化生をみることはなかつた．腺上皮 化生部では表層細胞は円柱状となり，核は基底部に配列 し, 少数の杯細胞を混じている. 粘膜固有層のリンパ 球, 好中球の浸潤程度は症例により異なる.

2) 第 1 度移行上皮癌 (2 例)

二例は米粒大と大豆大で小さい乳頭腫瘍である．系状 に細い血管結合織を伴い絨毛状突起を出している.腫瘍 細胞は均一な形態を示し細胞異型および核分裂をほとん ぞ認めない（図 5 ).基底膜から表面まで10個内外の腫瘍 細胞が存在するが，核の長軸を基底膜に対して直交すよ 5に配列する（図6）.表層細胞に PAS 陽性粗大顆粒を 䏰め, 部分的に偽腺様变化をみる (図 4).症例15では表 㬝細胞に糖原顆粒を認めた.

3）第 2 度移行上皮癌 (10例)

細胞異型が軽度に增加する。核の多くが棈円形で，そ の長軸を基底膜に対して垂直になるように配列している ことは第 1 度と同じであるが，核の大小不同，核クロマ

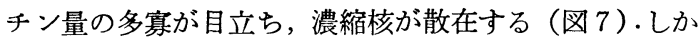
し核と細胞質が共に濃縮し, 細胞間結合が緩む所に出る 疃調細胞は認められない，腫瘍の一部にリンパ球が浸潤 している．核分裂はまれにみられるが多くはない，腫瘍 細胞の核・細胞質は增加する.

腫場の一部に淡明細胞集団が存在する，細胞質は淡明 化し，細胞膜が明瞭となり，石垣状を呈する（図 8).核 は濃縮性変化を示すため, 核異型が增加したようにみえ 各.この部分は clear cell type の腎癌の組織形態に似 ている、この部の細胞は diastase により消失する PAS 陽性の微細顆粒を充満している. 第 2 度の症例では糖原 陽性細胞集団がび慢性に出ることは少なく，腫崲の表層 
表 1

\begin{tabular}{|c|c|c|c|c|c|c|c|c|c|c|c|c|c|c|}
\hline$\left[\begin{array}{l}\text { 症 } \\
\text { 例 }\end{array}\right.$ & 氏 名 & 年令 & 性別 & 数 & 形態 & 大きさ & 発生部位 & 組織診 & 糖原 & $\mid$\begin{tabular}{|l|}
$\mathrm{B} G \mathrm{G}$ 表 \\
層細胞
\end{tabular} & \begin{tabular}{|l} 
偽腺様 \\
变化
\end{tabular} & $\begin{array}{l}\text { 扁平上 } \\
\text { 化生 }\end{array}$ & $\begin{array}{l}\text { 暲調 } \\
\text { 細胞 }\end{array}$ & 脱落 \\
\hline 1 & K. Y. & 78 & 贫 & 単 & $\mathrm{nP}$ & 米 粒 & 右尿管口 & III & + & - & + & - & + & + \\
\hline 2 & W. G. & 58 & $\hat{0}$ & 単 & $\mathrm{nP}$ & 小指頭 & 右尿管 & III & + & - & - & + & + & + \\
\hline 3 & S. M. & 53 & ? & 多 & $\mathrm{nP}$ & 三角部全体 & 三角部 & III & + & - & - & + & + & + \\
\hline 4 & O. C. & 68 & 0 & 多 & $\mathrm{nP}$ & 左半分 & 左半分 & III & - & - & - & + & - & + \\
\hline 5 & F. K. & 61 & $\hat{3}$ & 単 & $\mathrm{P}$ & 小 豆 & 後 壁 & II & - & - & - & - & + & + \\
\hline 6 & T. M. & 76 & $\hat{0}$ & 多 & $P$ & 米 粒 & 右側壁 & II & - & + & + & - & - & - \\
\hline 7 & M. S. & 70 & P & 多 & $\mathrm{nP}$ & 鵎 卵 & 頂 部 & III & + & - & - & + & + & + \\
\hline 8 & N. T. & 59 & $\hat{o}$ & 多 & $P$ & 粟 粒 & 後 壁 & II & + & - & + & - & - & - \\
\hline 9 & O. M. & 60 & $\hat{0}$ & 多 & $\overline{\mathrm{P}}$ & 小 豆 & 左尿管口 & II & + & + & + & - & - & - \\
\hline 10 & T. K. & 51 & $\hat{0}$ & 単 & $\mathrm{nP}$ & 鷄 卵 & 三角部 & III & + & - & - & - & + & + \\
\hline 11 & S. G. & 78 & $\hat{0}$ & 単 & $P$ & くるみ & 頂 部 & II & - & + & + & - & - & - \\
\hline 12 & O. $\mathrm{s}$. & 70 & $\hat{0}$ & 多 & $\mathrm{nP}$ & 拇指頭 & 左尿管口 & III & - & + & + & - & + & + \\
\hline 13 & K. M. & 64 & $\hat{o}$ & 単 & $\mathrm{nP}$ & 全 体 & 全 体 & SCC & - & - & - & + & - & + \\
\hline 14 & I. N. & 74 & $\hat{0}$ & 単 & $\mathrm{nP}$ & 左半分 & 左半分 & III & - & - & - & - & - & $t$ \\
\hline 15 & K. Y. & 57 & 우 & 単 & $\mathbf{P}$ & 大豆大 & 頂 部 & $\mathrm{I}$ & + & - & - & - & - & - \\
\hline 16 & H. M. & 51 & $\hat{0}$ & 単 & $\mathrm{P}$ & 拇指頭 & 左尿管口 & II & + & - & - & - & - & - \\
\hline 17 & T. K. & 70 & 우 & 単 & $\mathrm{P}$ & くるみ & 左尿管口 & II & + & + & + & - & - & - \\
\hline 18 & Y. Y. & 61 & 우 & 単 & $\mathbf{P}$ & 謟 卵 & 後 壁 & III & + & - & - & + & + & $t$ \\
\hline 19 & S. Y. & 74 & 少 & 単 & $\mathrm{nP}$ & 拇指頭 & 左尿管口 & II & + & - & - & - & - & + \\
\hline 20 & K. Y. & 52 & $\hat{\delta}$ & 多 & $\mathbf{P}$ & くるみ & 頂 部 & III & - & - & - & - & + & + \\
\hline 21 & T. K. & 64 & 우 & 多 & $\mathbf{P}$ & 拇指頭 & 右尿管口 & II & + & + & + & - & - & - \\
\hline 22 & S. K. & 41 & $\hat{0}$ & 単 & $\mathbf{P}$ & くるみ & 左尿管口 & I & - & + & + & - & - & - \\
\hline$\overline{23}$ & N. T. & 49 & $\hat{\jmath}$ & 単 & $\mathbf{P}$ & 拇指頭 & 右尿管口 & II & + & - & + & - & - & - \\
\hline
\end{tabular}

$\mathrm{P}$ : 乳頭状腫瘍。 $\mathrm{nP}$ : 非乳頭腫瘍。大きさおよび発生位置は生検した腫瘤.

$\mathrm{SCC}$ : 扁平上皮癌。BG表層細胞：PAS陽性粗大顆粒を有与る表層細胞.

扁平上皮化生：電顕的に確認された症例を含む.

にみられることが多い，時に糖原陽性細胞が陰性細胞の 間に散在することがある（図 9 ).腫瘍の糖原陽性部分は 10 例中 7 例に認められた.

糖原とは無関係に腫瘍最表層に diastase 消化に抵抗す る PAS 陽性粗大顆粒を認める（図10）。これらの空胞 は電䫓的に巨大顆粒 (big granule) に相当するものであ る $^{13) 14)}$. 巨大顆粒は 5 例に認められ，同時に腫瘍表面が 偽腺様变化を示していることが注目された（図10，11）。

腫湯表面の偽腺様变化は 10 例中 7 例涊められた. こ れらの例では表層細胞間の結合が強固で腫瘍細胞の脱落 所見はみられない，腺腔を縁取る細胞に巨大顆粒を認め ることが多い，偽腺様变化とは別に腫瘍細胞の変性崩壊 によつて生ずる变性空胞がみられる（因13-16).腫瘍細 胞の核周囲が空泡化し (図12), 部分的に腫瘍細胞が消失 し間吵を形成する，偽腺腔を縁取る細胞は空泡ないし濃
縮萎縮を示し，巨大顆䊉を所有する表層細胞を認めるこ とはない（図12～14）.変性空胞は腫瘍表層にかぎらず深 部にも存在する（図14）ここのよな間腔の中にはしばし ば PAS 陽性均質物質の充満（図15），ないし小空泡を 多発し，泡沫細胞化した腫瘍細胞の散在（図16）を認め る. かかる変性空胞は程度の差はあるが, 大多数の症例 に認められる. 変性空胞は腫瘍表面にだけ生ずる偽腺様 変化と区別されなければならない。

10例中 2 例に腫瘍細胞の強い脱落がみられた（因17）. かかる症例（症例 5 , 症例19）では細胞間隙が増し, 細 胞間の結合は緩み，多数の腫瘍細胞が脱落過程を示して いる. 脱落を示す腫汪に巨大顆粒を有する最表層腫汮細 胞ないし偽腺様変化は認められない, 腫瘍内に暗調細胞 が增加している. 暗調細胞は細胞間接着を緩め, 核, 細 胞質とも濃縮し，核形は不整となる（図18）。細胞の脱 

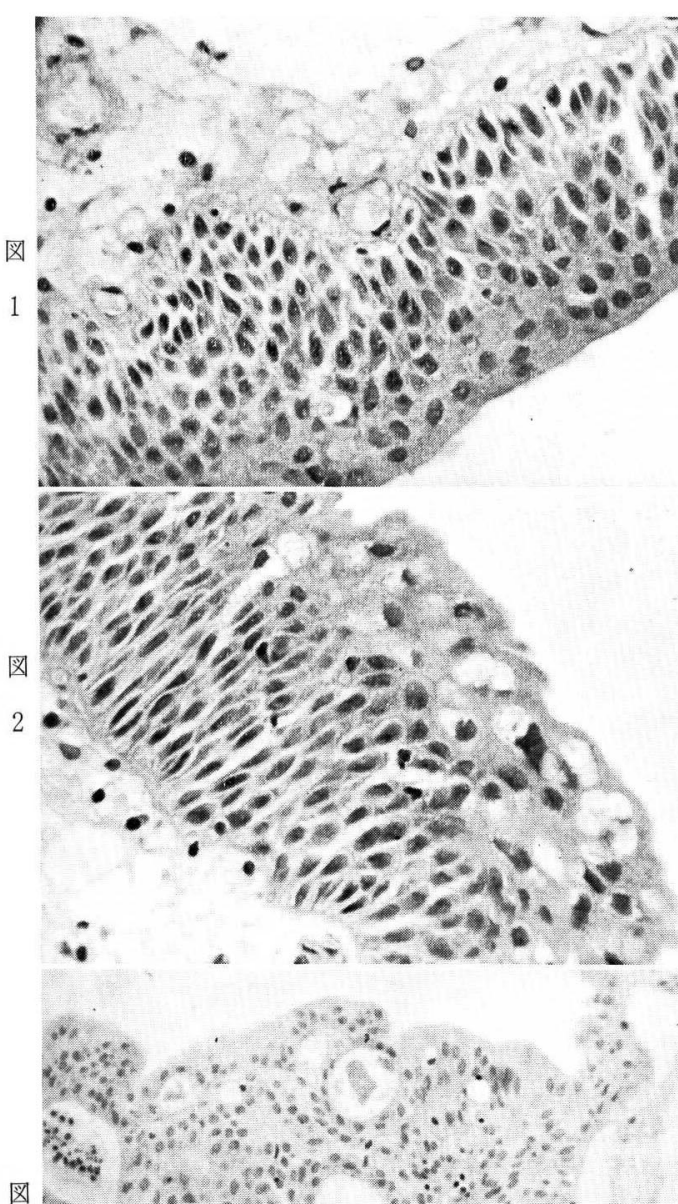

図,

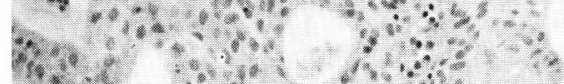

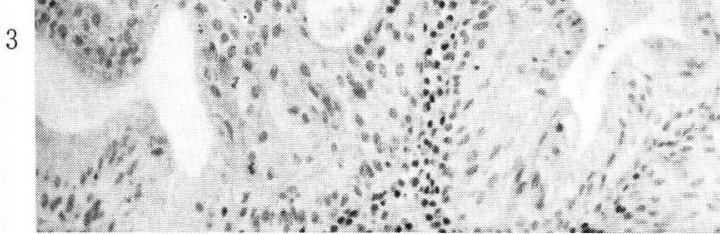

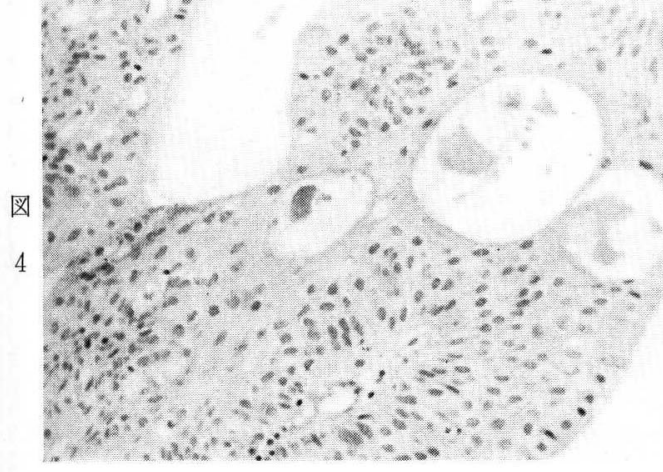

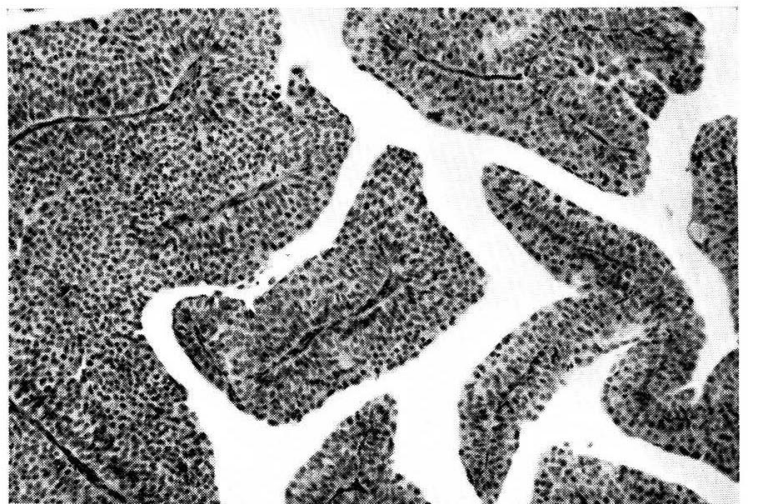

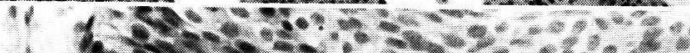

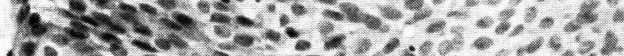

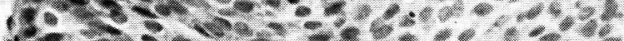

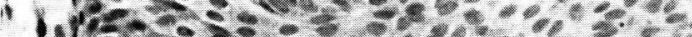

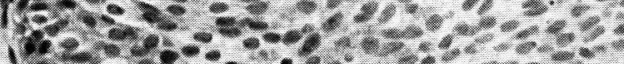

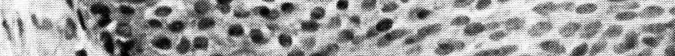

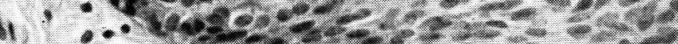

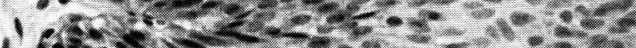

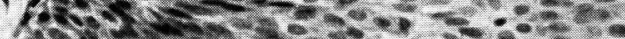

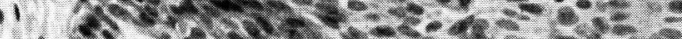

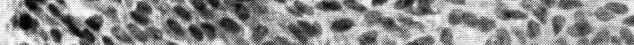

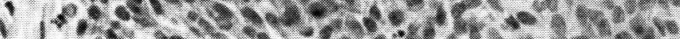

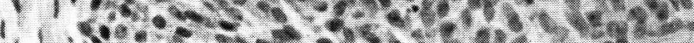

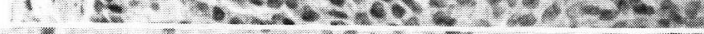

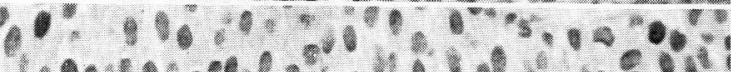

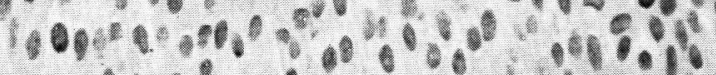

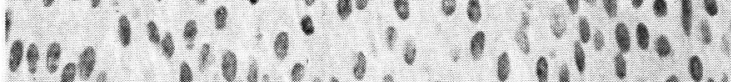

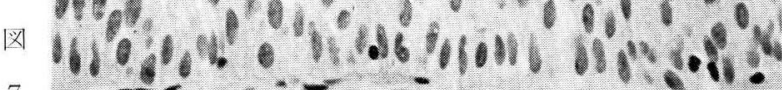

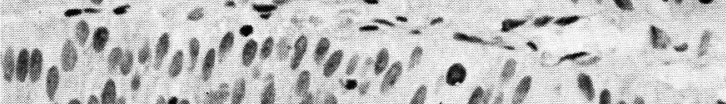

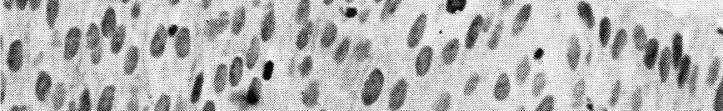

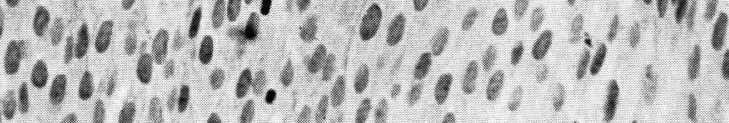

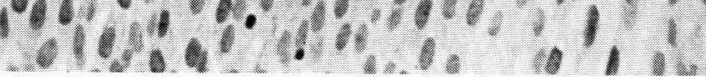

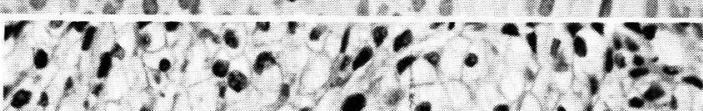

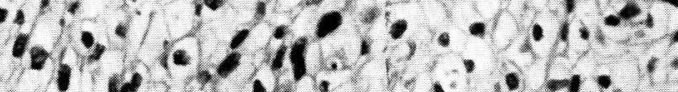

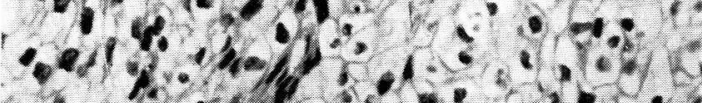

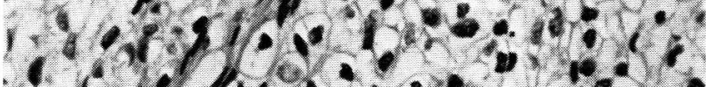

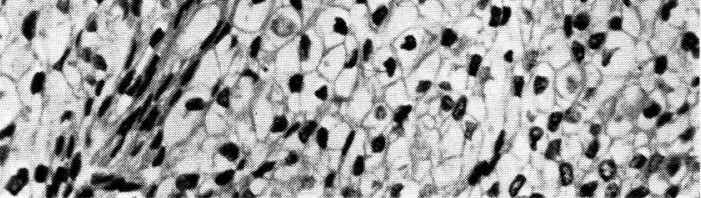




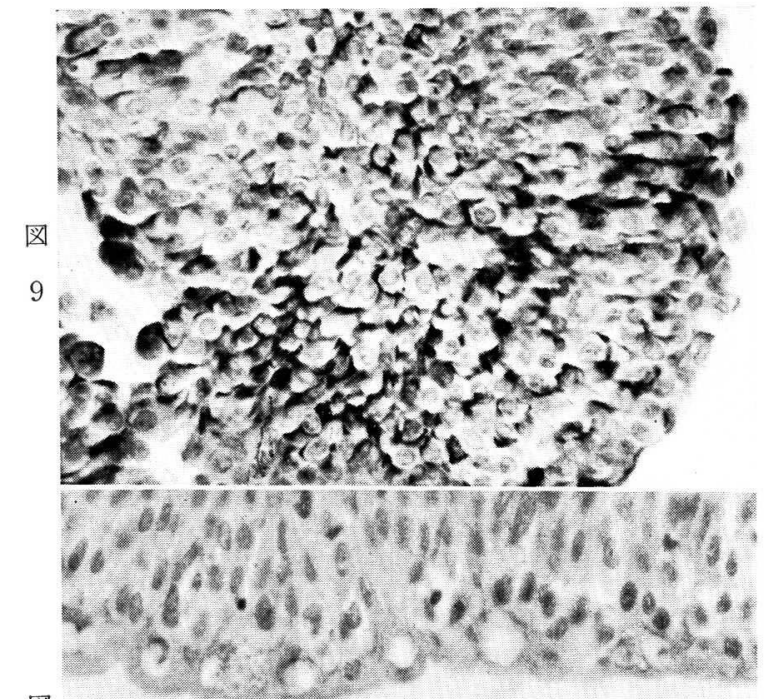

図

10

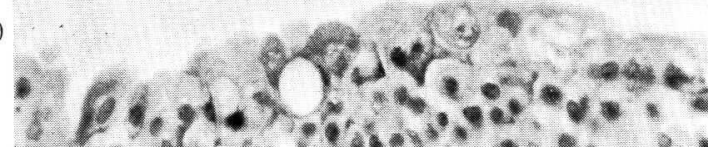
$2 x^{2}$

図:

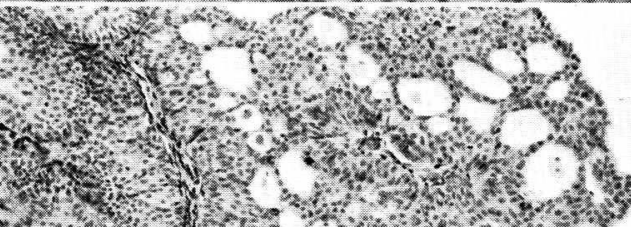

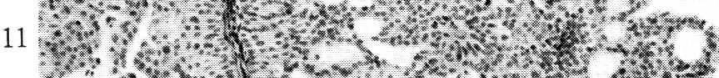
स.

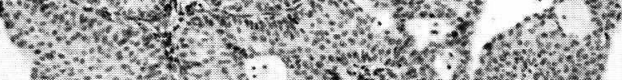

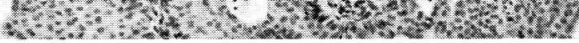

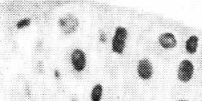

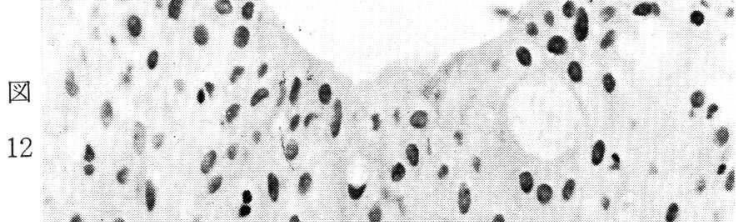

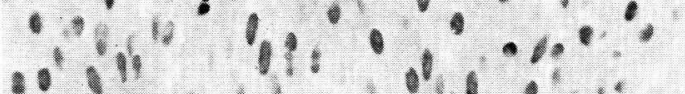

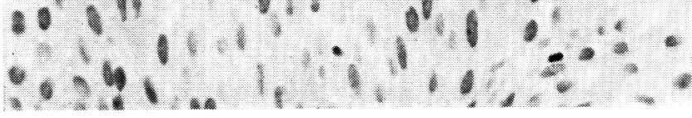

図

図

14

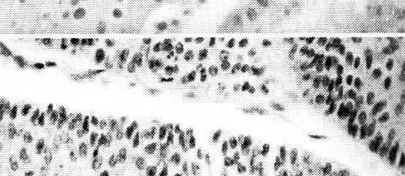
is

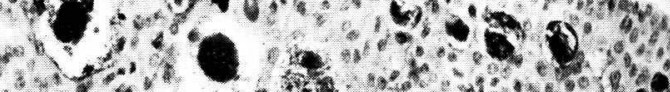

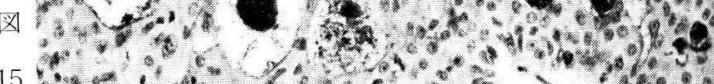

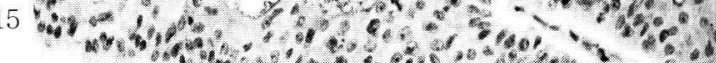
is

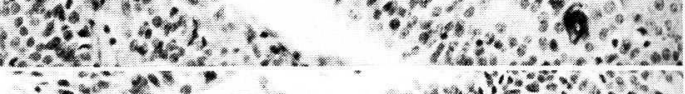

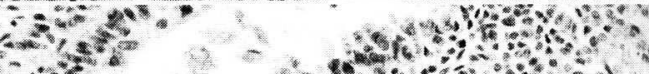

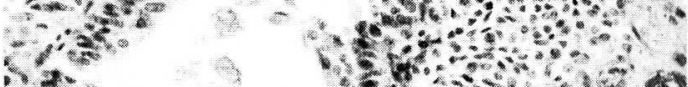
in:

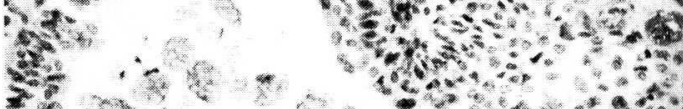

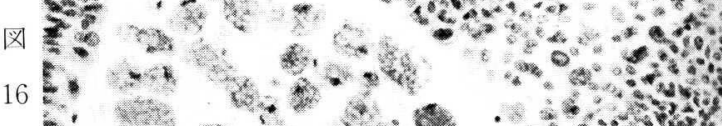

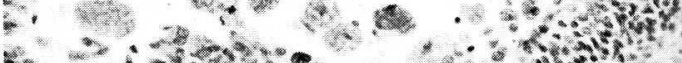

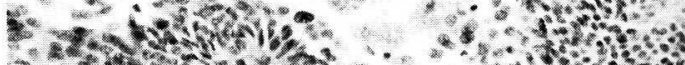

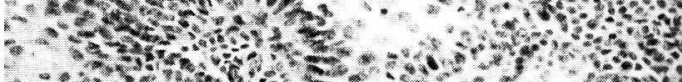
inos 0 -

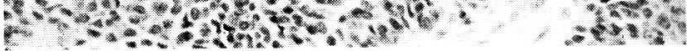




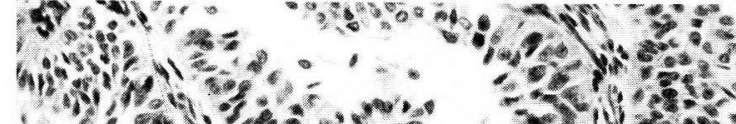

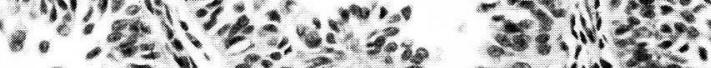

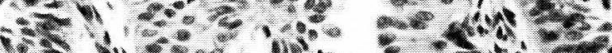

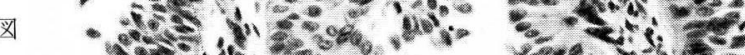

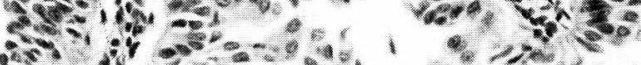
Fin

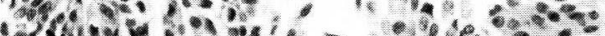
"x(20)"

2. $-20^{2}=7:=$

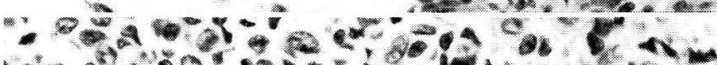

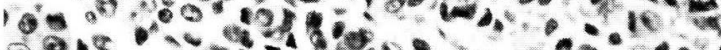
a

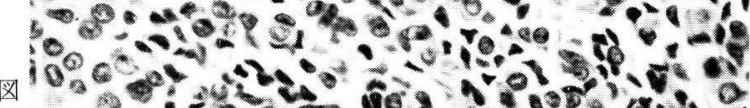

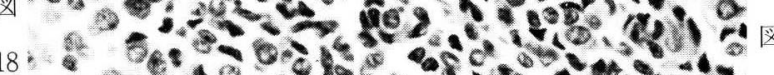

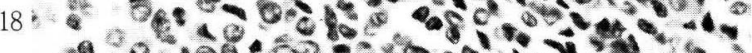

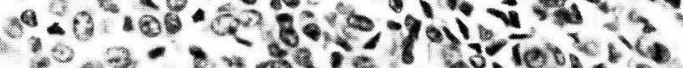
O.

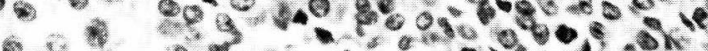

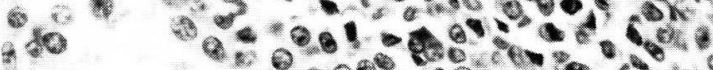

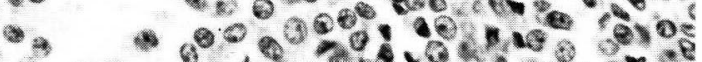

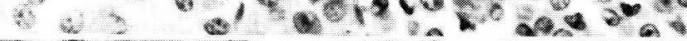

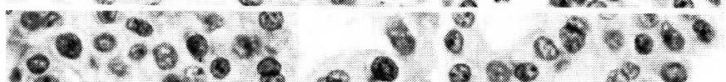

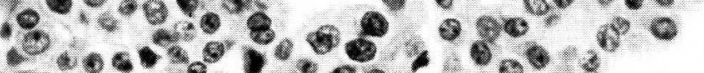

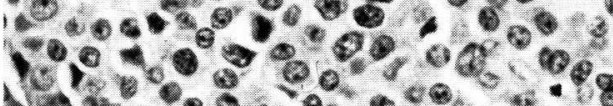

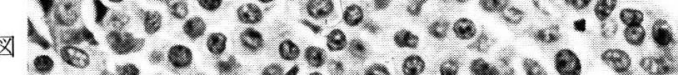

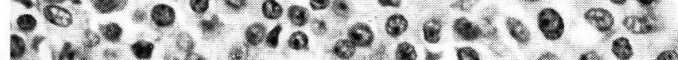
\%

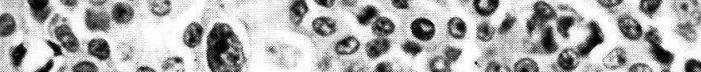
- $0.020 .0 \%$ $2.04000^{\circ} 0^{\circ} x^{\circ}$.

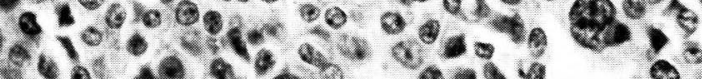

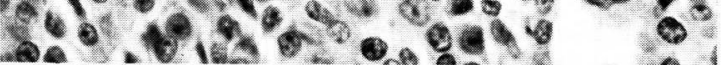

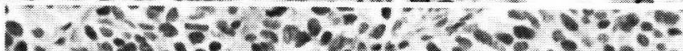

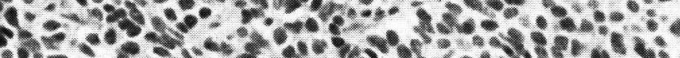

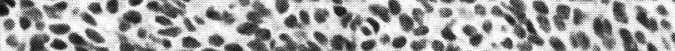

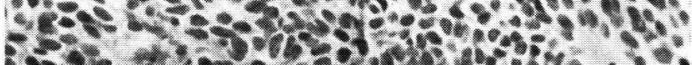

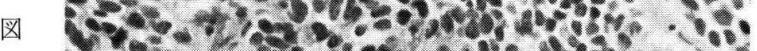
: 5 -

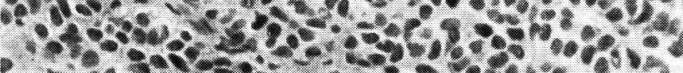

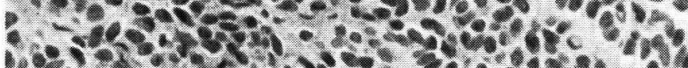

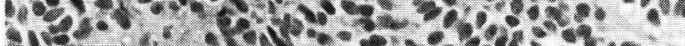

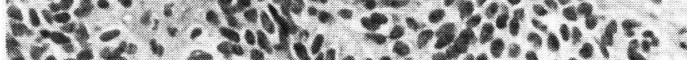

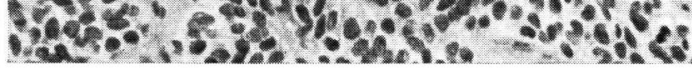

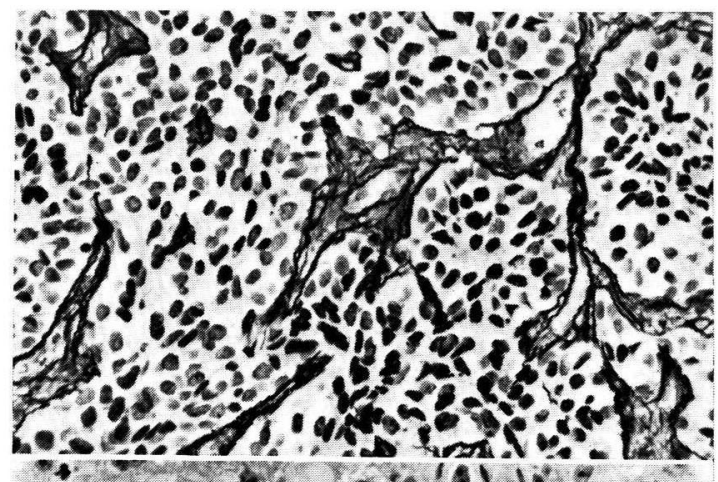

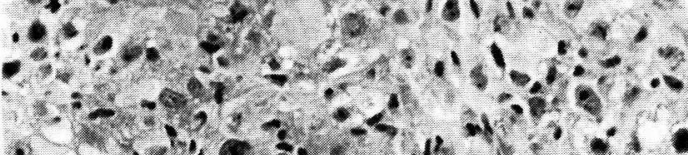

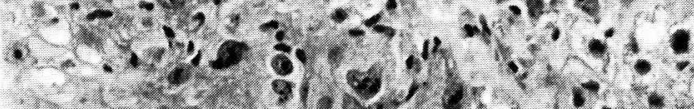

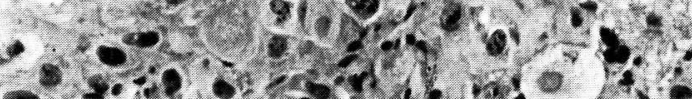

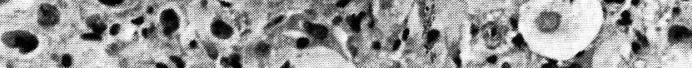

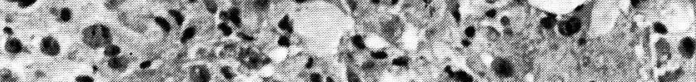

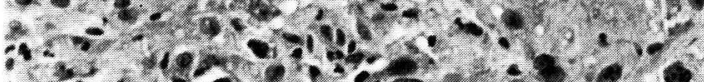

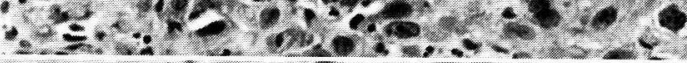

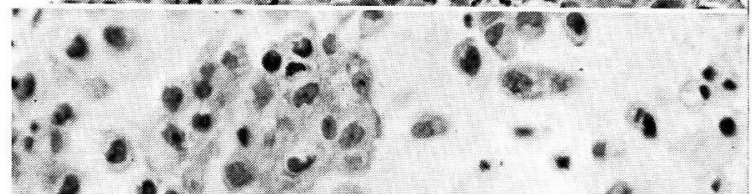
淿
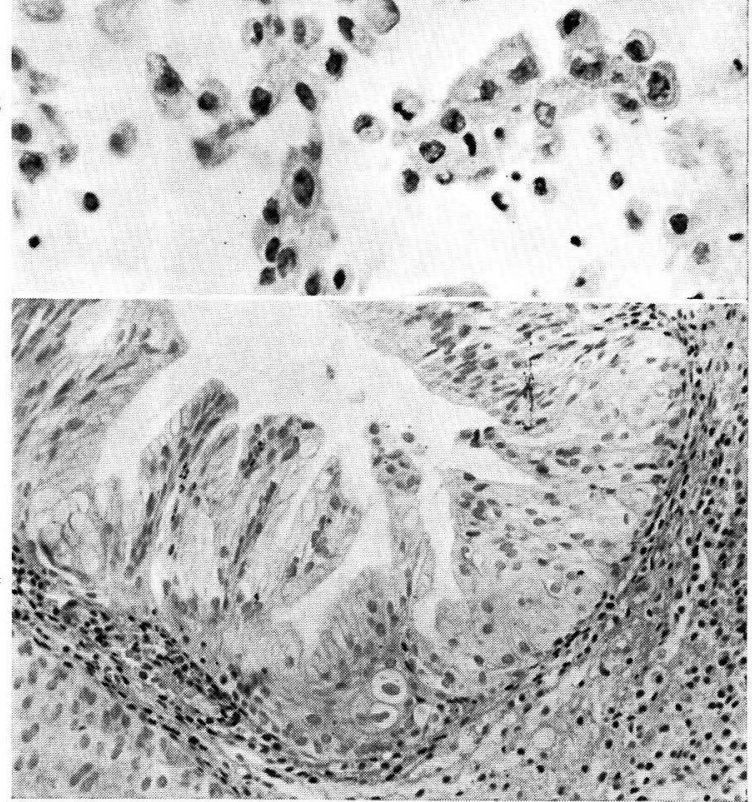


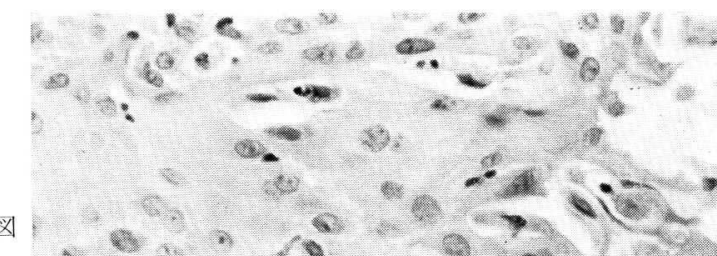

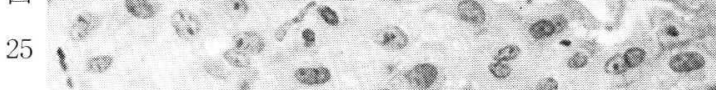

$$
\begin{aligned}
& e^{\circ}
\end{aligned}
$$

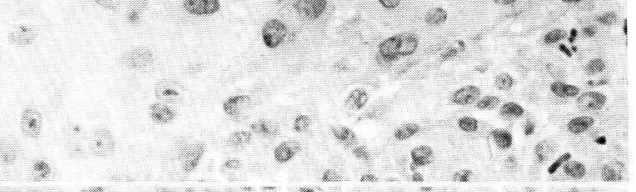
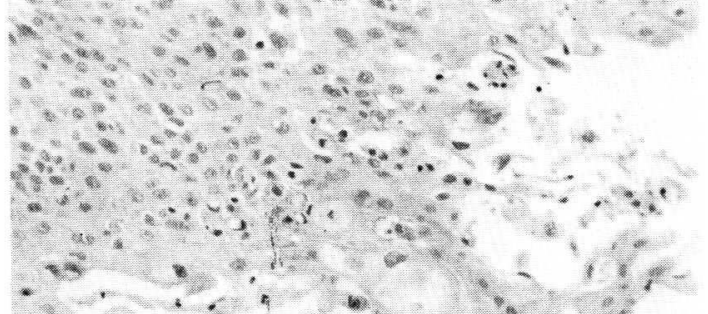

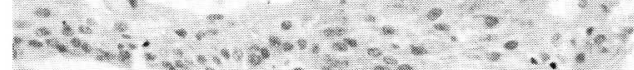

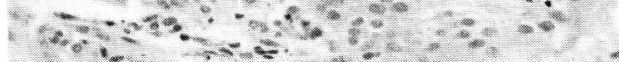

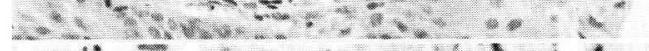

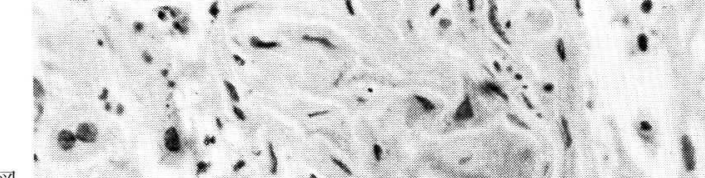

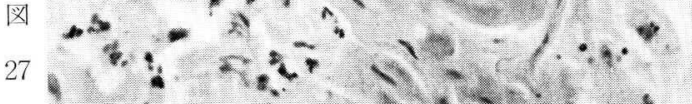

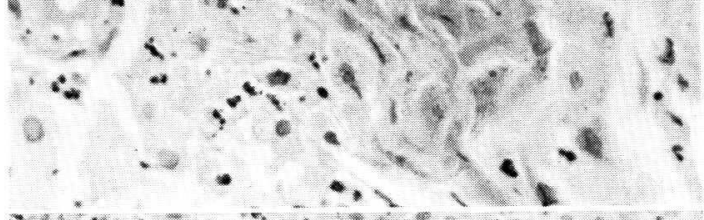

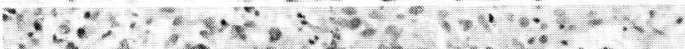

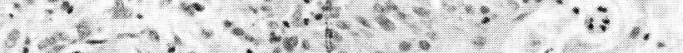

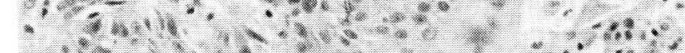

図

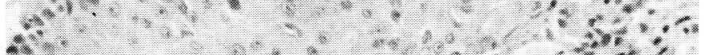

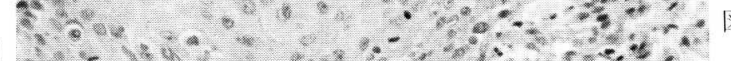

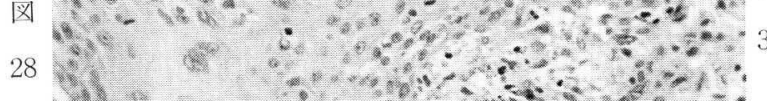

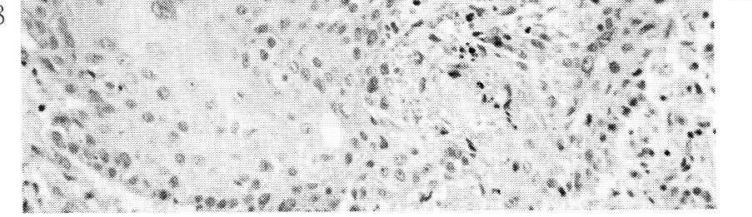

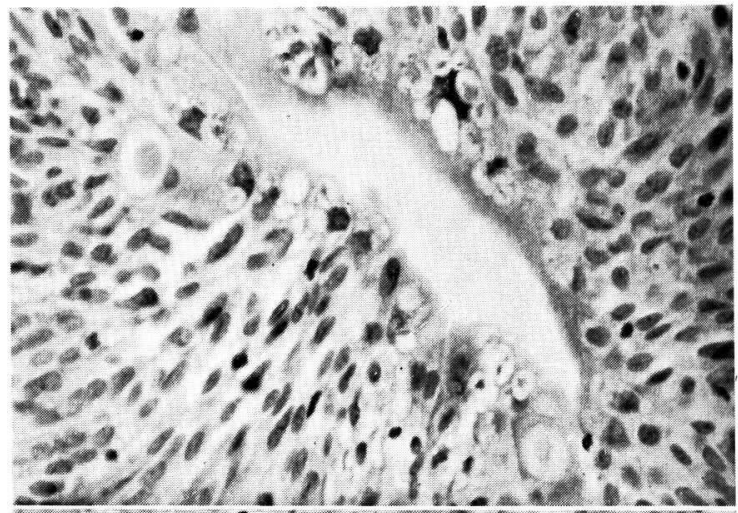

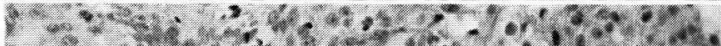

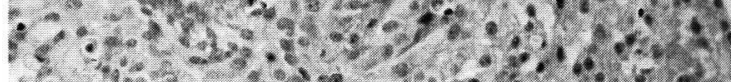
,

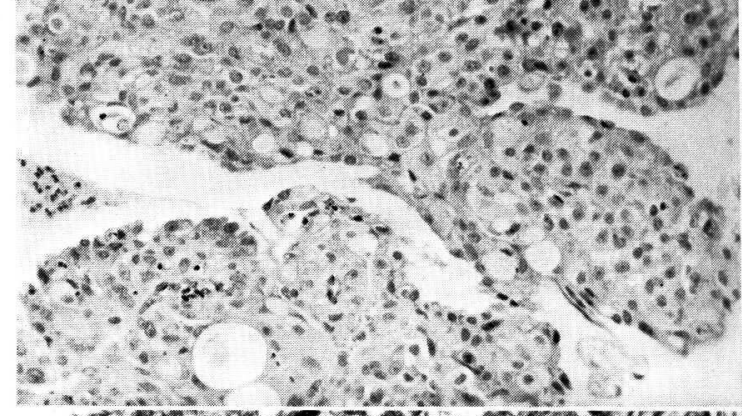

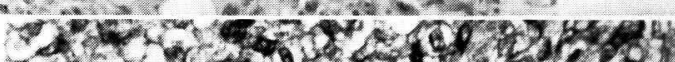

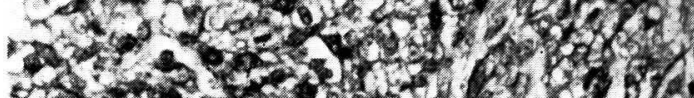

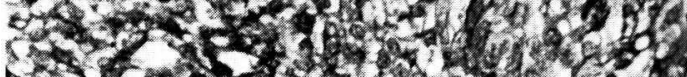

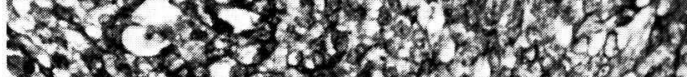

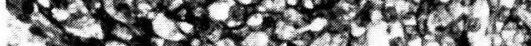

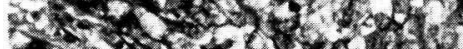

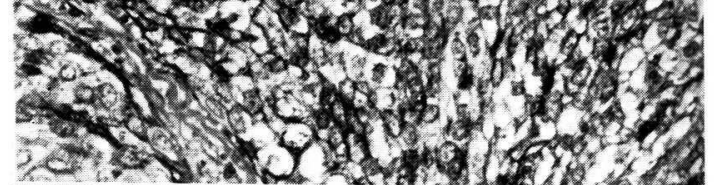

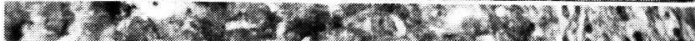

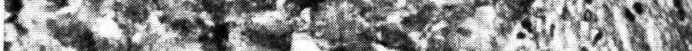

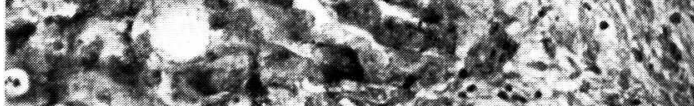

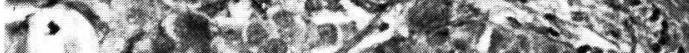

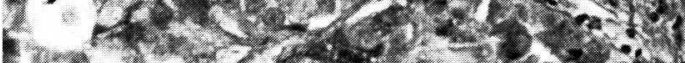

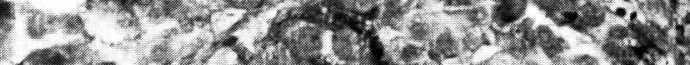

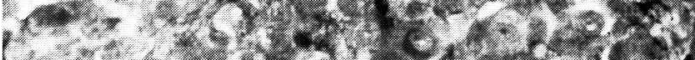

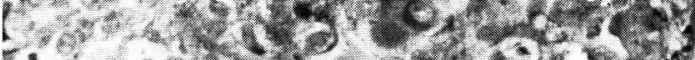

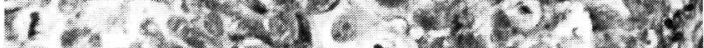

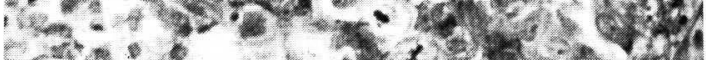



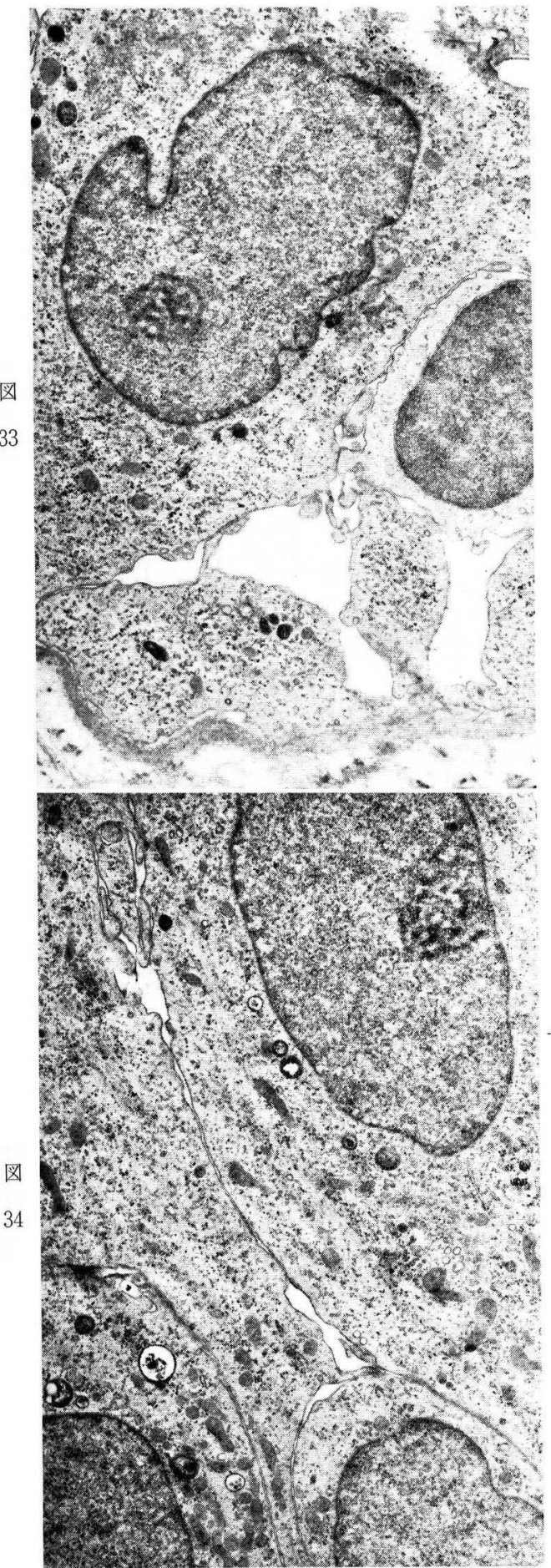

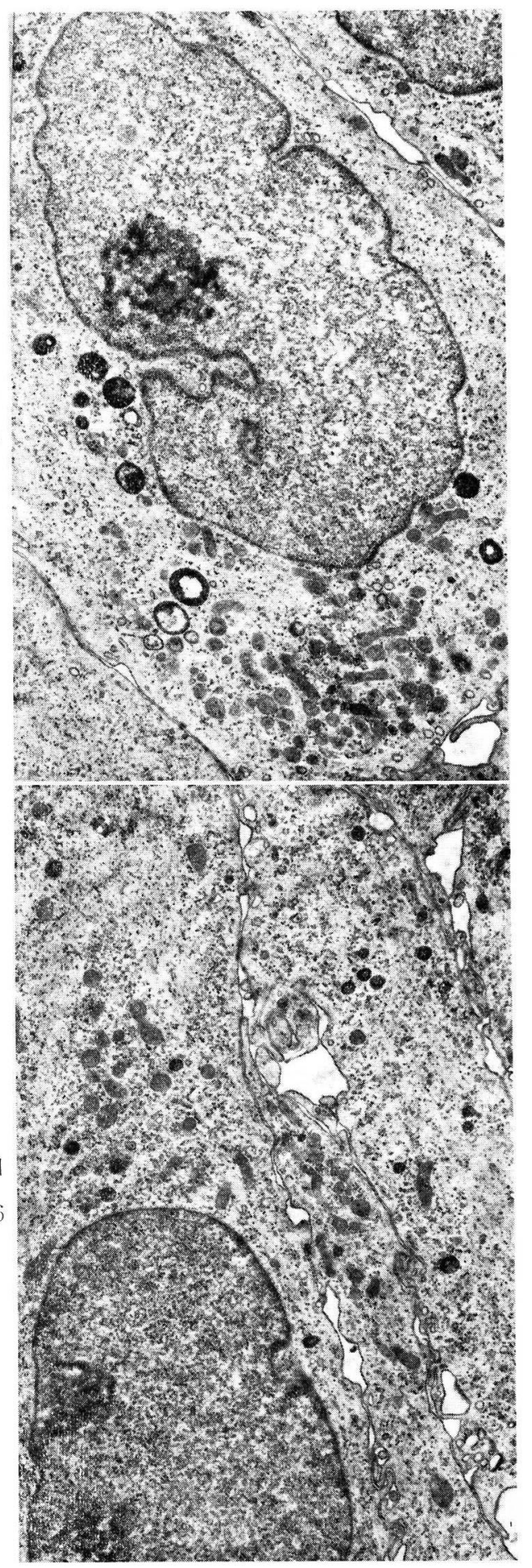




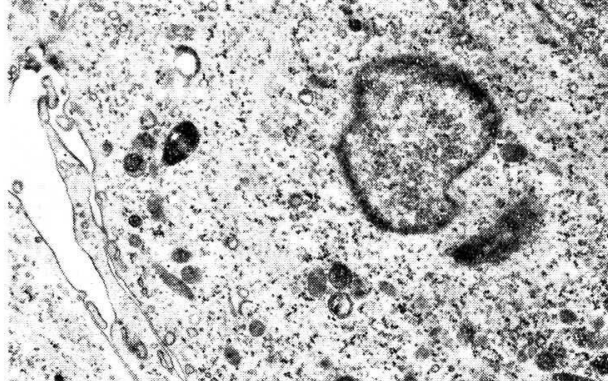

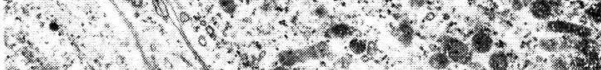

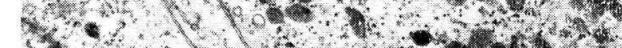

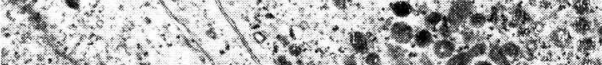

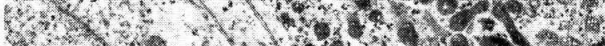

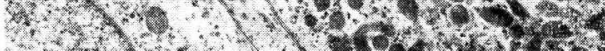

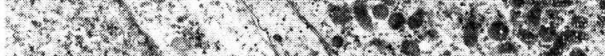

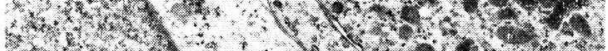

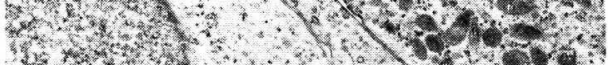

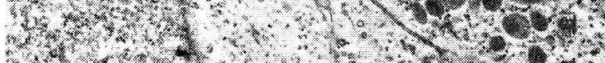

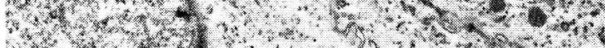

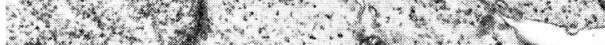

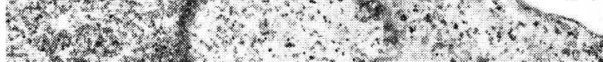

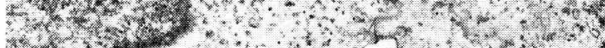

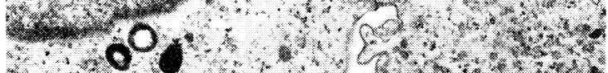

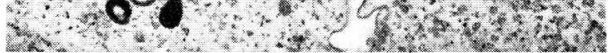

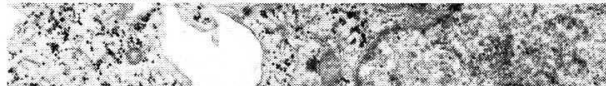

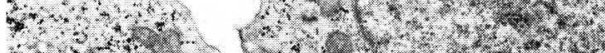

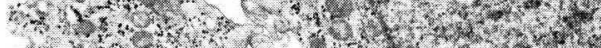

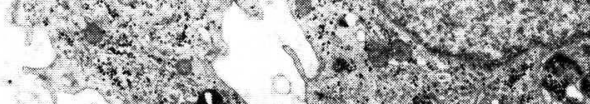

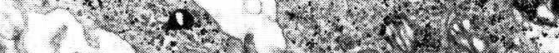

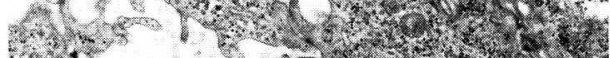

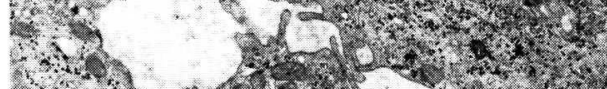

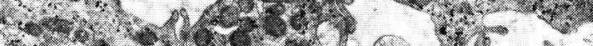

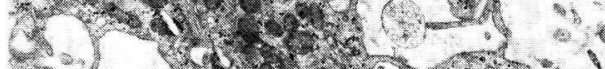

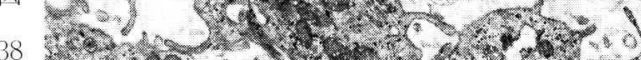
3.3.

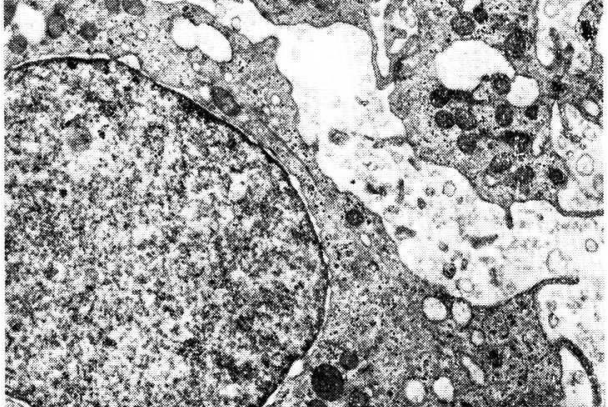

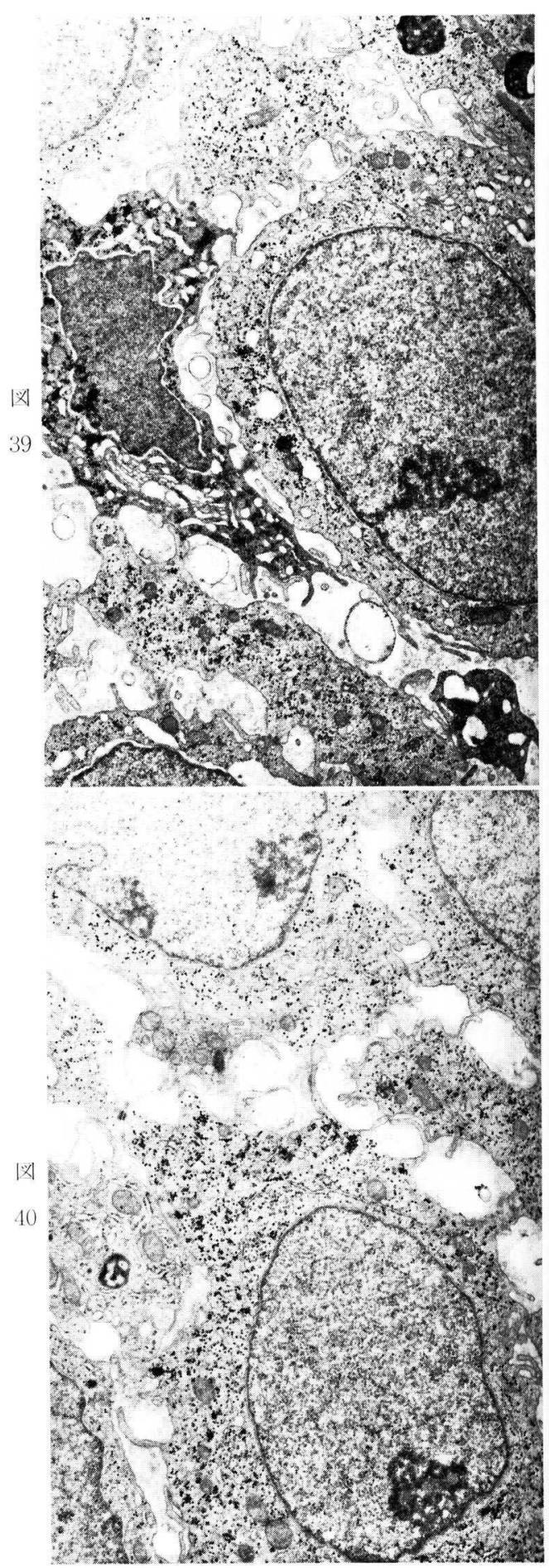




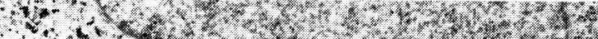

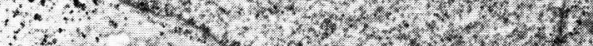

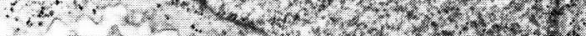

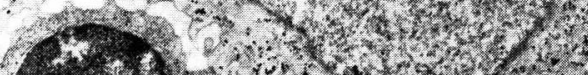

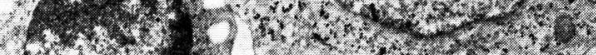
(n) $-10$

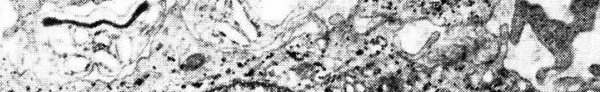

antse

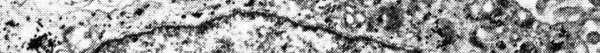

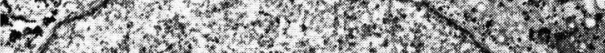

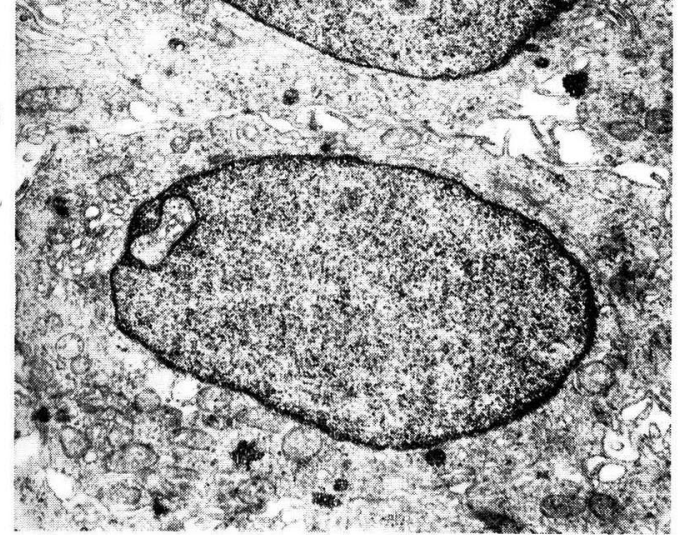

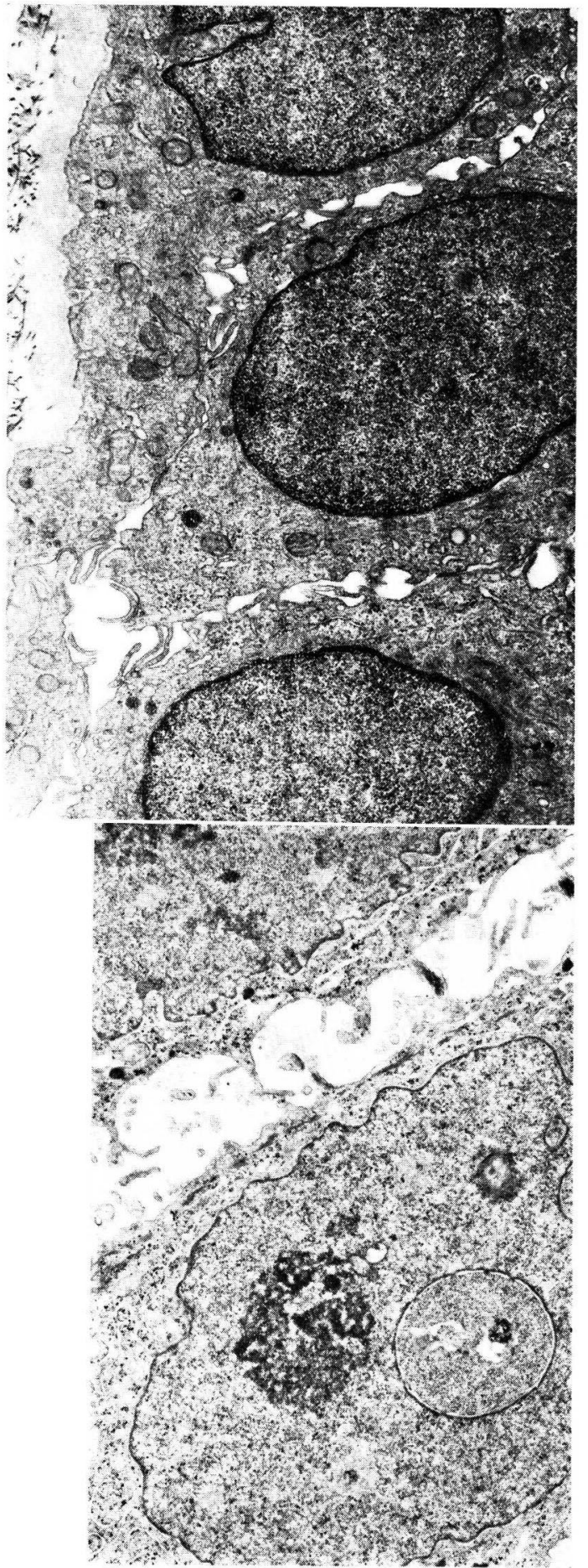



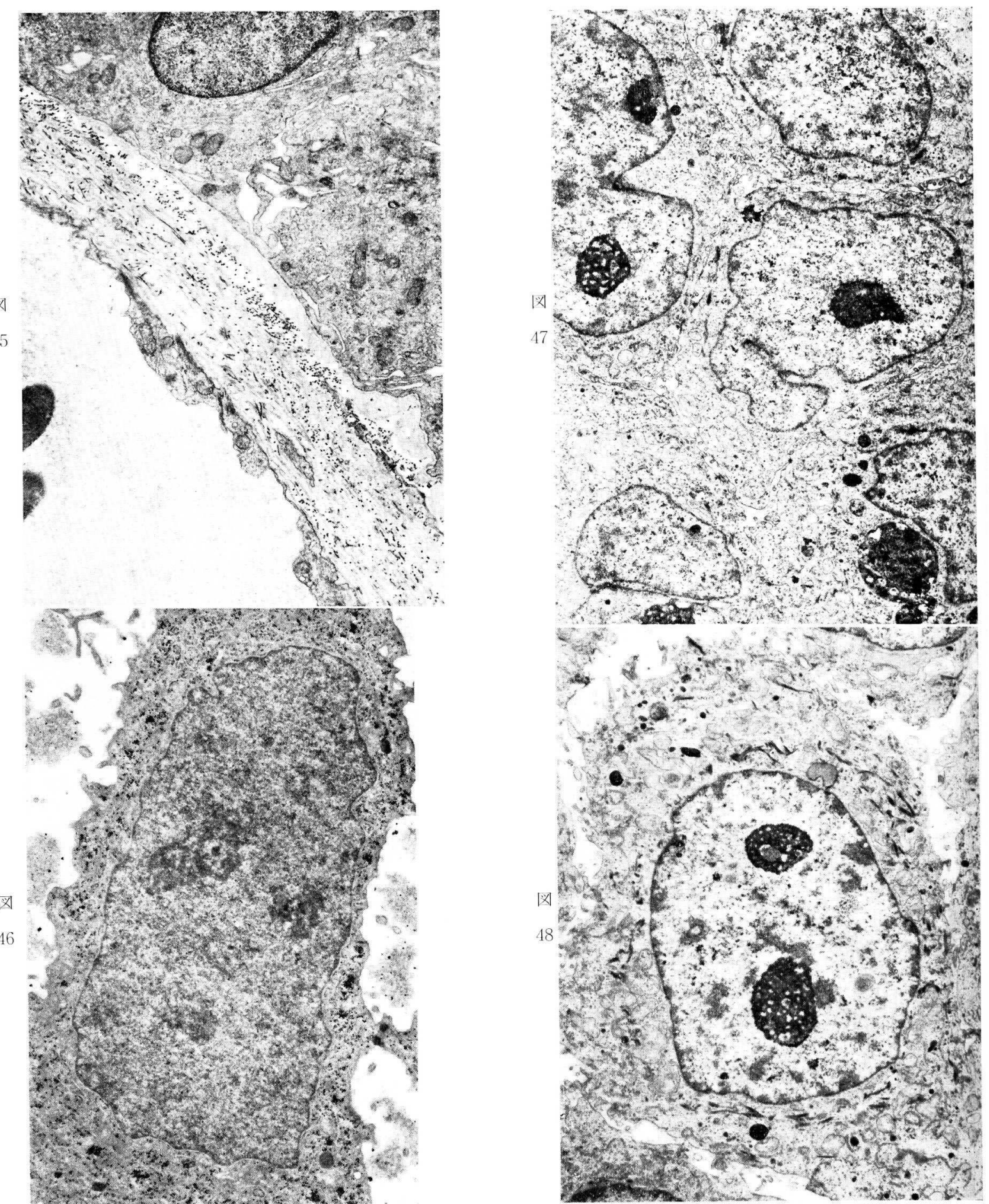


\section{付図説明}

図 1 腫瘍に接する膀胱粘膜（症例 4), 粘膜上皮の spongiosis, 粘膜下組織の浮腫が目立つ。 $\times 300$, H-E.

図2腫瘍に接する膀胱粘膜（症例 4).表層細胞内 細胞質空泡が多発している。 × 300, H-E.

図 3 膀脱粘膜の腺様化生（症例14）.腺腔に P A S 陽性物質を認める。粘膜下にリンパ球, 形質 細胞の浸潤をみる。 $\times 150$, H-E.

図 4 腫瘍表面の部分的偽腺椂変化（第 1 度, 症例 15).腺腔に小量の P A S 陽性物質を認める. $\times 150$, H-E.

図 5 膀胱乳頭腫 (第 1 度, 症例 22). 腫瘍は乳頭状 発育を示す。 $\times 60$, H-E.

図 6 移行上皮癌（第 2 度, 症例 6).核細胞質比が 増加し, 細胞は密在する。核は基底膜に垂直 に配列する。 $\times 150$, H-E.

図 7 移行上皮癌(第 2 度, 症例 9).核の大小不同, 濃淡がみられる。 $\times 150$, H-E.

図 8 糖原陽性細胞集団（第 2 度, 症例17).淡明細 胞の集団で細胞膜が石垣状で明瞭である。核 は濃縮するために核異型が増加したようにみ える. × 150, H-E.

図 9 糖原陽性腫瘍細胞之陰性細胞（第 2 度, 症例 17）。糖原陽性細胞は表層部に多い。陰性細胞 が混在する。 × 150, PAS 染色.

図10 PAS 陽性粗大顆粒 と空泡を示す腫場最表層 （第 2 度, 症例 21).PAS 陽性物質は凝集し て空泡の中心に位置するものが多いが，空虚 な空泡もみられる。 × 150, PAS 染色.

眓11腫瘍表面の偽腺樣変化（第 2 度, 症例23）.腫 瘍内に間腔が散在する。右方の腫瘍表面は平 滑であり,偽腺様変化は部分的である。 $\times 60$, H-E.

眓12腫瘍細胞の空泡化と変性空泡（第 2 度, 症例 11）.腫瘍表層に核に接して空泡が多発してい る。腫瘍細胞は部分的に変性消失して偽腺腔 を形成している。 × 150， H-E.

図13腫瘍細胞の空泡化と変性空泡（第 2 度, 症例 11).腫瘍細胞の核周囲に始まる空泡化と小偽 腺腔. $\times 150$, H-E.

図14腫瘍細胞空泡化之変性空泡（第 2 度, 症例 16).偽腺腔に好酸性均質物質を認める。腺膑 を緑取る腫瘍細胞は圧迫されて扁平化濃縮し ている. × 150, H-E.

図15 PAS 陽性物質を充満する変性空胞（第 2 度, 症例 5 ).腫瘍組織内に生じた偽腺腔内にPAS 陽性物質が充満している，腺腔を縁取る腫瘍 細胞に PAS 陽性粗大顆粒は認められない. $\times 150$, PAS 染色.

図16 間腔内に散在する泡沫腫瘍細胞（第 2 度, 症 例 8).間腔内に泡沫細胞化した脱落変性腫瘍 細胞が散在する。脱落細胞は PAS 反応陰性
である。 × 150, PAS 染色.

図17腫痬細胞の脱落（第 2 度, 症例19）.腫瘍表面 は強く細胞脱落像を示す。表層細胞, 偽腺様 変化は認められない。 $\times 150$, H-E.

図18暗調細胞（第 2 度, 症例19）。腫瘍細胞間隙が 開き，核細胞質ともに濃縮した dark cell を 多数認める。 $\times 150$, H-E.

図19巨核腫湟細胞（第 3 度，症例18）.腫瘍細胞は 核，細胞質比を増し，核小体は肥大する。核 分裂と暗調細胞を散見する。2 個の巨核腫瘍 細胞をみる。 $\times 150$, H-E.

因20 第 3 度腫瘍組織 (症例20). 核・細胞質比の大 きい腫瘍細胞が密在し癌巣焉形成している。 間質は複雑に癌巣内に入り込む。 × 150 , H-E.

図21第 3 度腫瘍組織（症例20）。鍍銀染色で癌巣と 間質の区分は明瞭となる。核異型と核ク口マ チン量の多寡が目立つ。 $\times 150$, 渡辺鍍銀染 色.

図22扁平上皮化生部（第 3 度，症例 2).腫瘍細胞 の大小不同, 細胞質肥满, 細胞膜の明瞭化な どをみる，空泡化細胞が混在する，細胞間橋 は明瞭でない，周囲移行上皮癌部分からの移 行がみられる。 × 150, H-E.

図23低形成移行上皮癌（第 3 度，症例14）。腫瘍細 胞は小形円形であるが，細胞間の付着性が悪 く，核異型は強い，第 4 度ともみなすことが 出来る。 $\times 150$, H-E.

図24腺癌部分の混在（第 3 度, 症例 1 ).第 3 度の 腫瘍表層に腺様化生部が混在する。粘液産生 性杯細胞化癌細胞を多数認める。 $\times 150$, H-E.

図25扁平上皮化生巣（第 3 度，症例 7 ）.細胞質は 肥满し，細胞間橋を部分的に認める。表層に 角化細胞を認める。 $\times 300$, H-E.

図26扁平上皮化生巣（第 3 度, 症例 3 ）表層脱落 細胞は角化傾向を示す。 $\times 150$, H-E.

网27扁平上皮癌（扁平上皮癌, 症例13）腫煌内の 癌真珠。角化細胞内に好酸性顆粒を認める。 $\times 150$, H-E.

図28扁平上皮癌（扁平上皮癌，症例13）間質に接 する腫瘍細胞は小円形で, 癌巣中心部に肥満 細胞, 角化細胞が存在し, 扁平上皮の成熟過 程を模做している。 × 150, H-E.

図29偽腺梯変化と粗大顆粒を含む表層細胞（第 3 度, 症例12）表層細胞は空泡を有し，中に PAS 陽性粗大顆粒を入れている。かかる空 泡は腫湯深部にも散在する。 × 300, PAS 染 色.

図30 扁平上皮化生巣（第 3 度, 症例 4 ) 化生部分 の腫瘍細胞は水腫変性を示し, 所々で為腺腔 を形成する。 × 150, H-E.

図31 焙原陽性腫瘍細胞（第 3 度, 症例18）深部腫 
瘍細胞に PAS 陽性微細顆粒かひ漫性に存在 する. $\times 300$, PAS 染色.

図32扁平上皮化生部の糖原陽性（第 3 度，此例 2) 移行上皮癌より移行する化生部分では糖原陽 性である(図22と同一視野).× 300, PAS 染 色.

図33 第 1 度腫場細胞（淀例15）細胞質に遊離 ribosome j增加しているが, organelle にミし い。腫雹細胞間の結合はゆるみ, リンパ球か 浸潤している。基底膜は閚く明登てある。 $\times 7,000$

济31第 2 度䛲瘍細胞（症例 5 ） Golgi 装置，系粒 体, lysosome なとつ細胞質小器它打增加し, 細胞質基質には微細線維と遊離 ribosome 增加している。 $\times 7,000$

図35第 2 度腫場細胞（症例 5 ）核は大型化し, 細 胞の中央に位置する。型系粒体が増加し細 胞質の 1 側に集合している。 lysosome は大 型化し空泡化しているものかある。 × 7,800

図36 第 2 度腫瘍細胞（症例 5 ）細胞間の接着装置 は減少している。 × 7,800

図37 第 2 度腫瘳細胞（症例 6 ）小型系粒体加増加 し, 細胞質の 1 側に密在している。 $\times 7,000$

図38 第 3 度腫堭細胞（症例 1) 細胞間陌か增加 し, 微䋐毛椂突起か多数認められる。 $\times 8,200$

図39第 3 度腫煌細胞（症例 1 ）暗調組胞加洞目随 瘳細胞と接着を保ち存在する。暗調細胞は 核，細胞質ともに濃縮しているか，glycogen 顆粒を保持している。 × 8,200

为40 第 3 度腫場細胞（淀例 1 ）細胞質基質の微紐 線維は減少し，長管状粗面小胞休か増加して
いる. glycogen 顆粒か＼cjkstart細胞犋に分布してい る. $\times 8,200$

図41第 3 度腫㻤細胞（症例 1) 核小体の肥大と nuclear body が核内部に認められる。細胞間 吵にリンパ球が浸潤している。 × 8,200

図42 第 3 度腫癔細胞（症例20）核輸遊の不 整, nuclear body の增加加目立つ。細胞質に glycogen 顆粒は存在しない。 $\times 13,000$

冈4 第 3 度腫瘍細胞（症例 20）細胞質基質に微細 線維と vesicular な滑面小狍体が增加してい る。下部に基底膜と膠原線維か梕められる。 $\times 13,000$

闵44 低分化腫瘍細胞（症例14）核・細胞質比は著 しく増加している。核輪廓の不整，核小体の 肥大と分散, perichromatine 顆粒の增加を認 める。 $\times 15,000$

図45第 3 度腫瘍細胞（症例20）腫瘍細胞と拡張し た静脈内皮細胞との間に基底膜，膠原線䧽， 層状の基底膜樣物質を認める。 $\times 8,000$

为46 低分化腫瘍細胞（症例 14）細胞間に接着装置 を認めず，細胞質は organelle にそしく，迶 離 ribosome が充満するだけて細胞質構造は 単純化している。 $\times 15,000$

図47扁平上皮癌細胞（症例13）核異型と核小体の 肥大が目立つ。細胞間に tonofilament-desmosome 結合を認めを。細胞貎に focal cytoplasmic degradation を認める。 × 6,000

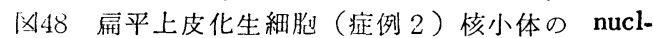
eolonemma が明瞭である。微細線維は束と なり核を取り囲んでいる。小数の lysosome が暗調顆粒として認められる。 × 8,000 
落, 暗調細胞化の強い症例で粘膜固有層の浮腫およびリ ンパ球浸潤の強いことが注目された.

4）第 3 度移行上皮癌（11例）

扁平上皮癌 1 例と末分化癌で第 4 度とみなされる 1 例 をこの症例群に抱括した.

腫瘍細胞の核・細胞質化は一層增加し，間質量は不定 である. 分化型癌にみる系状間質はみられなくなる.こ のことは大部分（７例）の腫瘍が非乳頭腫瘍である肉腿 所見と一致する。核分裂，暗調細胞の混在度，細胞異型 などが目立つ. 核の大小不同，クロマチン量の多寡が強 くなり，時に巨核細胞を認める（図19）.

症例により細胞密度が増し, 癌巣と間質の区別が不明 となる（図20）.鍍銀染色で始めて明瞭となる程癌巣と間

質が複雑に入り組んでいる（図21）。

腫瘍細胞に糖原を認めたのは11例中 6 例である. 第 III 度の腫瘍では糖原がび慢性に存在することが多い（図 31).扁平上皮癌は糖原陰性であつたが，移行上皮癌の扁 平上皮化生部分が糖原陽性であることが注目された（図 32).

偽腺様变化は 2 例（症例 1 , 症例12）に認められたが 部分的であり，巨大顆粒を有する表層腫瘳細胞は症例12 に認められた（図29）.症例12では部分的偽腺様変化のほ かに腺化生がみられた.この部の腫瘍細胞は内腔に向つ て乳頭性増生を示し，細胞は円柱化し，核は基底部に並 び，少数の杯細胞をまじえ腺癌組織を示している（図 24).

腫瘍表面の細胞脱落は程度に差があるが，全例に認め られた．同時に腫瘍細胞の結合の緩み，暗調細胞の混在 などが部分的ではあるが認められた.

10 例中約半数の 5 例の移行上皮癌組織内に扁平上皮化 生部分を認めた. 化生部は周囲の移行上皮癌に移行して いて，境界は不明である. 化生部では核分裂が増加し， 腫瘍細胞質は肥满している，細胞膜は明膫となるが，細 胞間橋は明瞭でないことが多い（図22）．腫瘍細胞の空 胞性变化が強くなり変性空泡を形成することがある（図 30).化生单が膀胱内腔に露出する所では少数の角化細胞 および細胞脱落をみるが，脱落程度は弱く，移行上皮癌 のように強い脱落を示すことはない（図25，26）.化生部 に角化細胞の散在をみるが县真珠の形成はみられない。 扁平上皮癌（症例13）では細胞間㛢，癌真珠の形成が認 められる（図27，28）.

\section{電顕所見}

1）第 1 度移行上皮癌
核膜の凹凸の程度は軽く円形ないし棈円形を呈する. 指状陥凹を 1 個有することが多い，核小体は小型で核膜 に接して認められる. 指状核陷凹部に接する細胞質に小 型の Golgi 装置を認める（図33）.細胞質には小型の系粒 体, lysosome と小量の粗面小胞体, 滑面小胞体の軽度 の発達を認める. 滑面小胞体は vesicular pattern を示 し, 細胞膜の近くに存在する.これら細胞質小器官の発 達程度は正常中間細胞の発達分布と似ている. 細胞質基 質には微細線維が発達しているが，その量は正常細胞と 同じである，遊離 ribosome は細胞質基質に増加してい る.

表層腫瘍細胞には正常細胞同样に限界膜に囲まれた 巨大顆粒を涩めるが， compressed vesicle は認められな い. 細胞間の desmosome の数は减少し, 細胞間䣣は軽 度增大し, 細胞質の微絨毛突起が増加する. 最表層細胞 を除くと表層細胞と基底膜に接して存在する細胞の間に 特別の差異は認められない. また細胞睤小器管の分布に 特別の極性を認めることはない。

2）第 2 度移行上皮癌

核は増大し輪廓は一㢖不整となる.ために核・細胞比 は増大している．核は組かい凹凸のほかに第 1 度の細胞 核同様，深く大きな核陥凹を示寸ことが多い（図35）。切 断面にもよるが核小体も大型化し，2 個有する核がみら れる（図36）.ときに nuclear body を核質内に認めるこ とがある。

細胞質構造で注目されることは糸粒体と lysosome の 発達がよく，数の增加がみられることである. 系粒体は 小円形ないし短棒状であるが，その長軸の長さは不定で かなり長い糸粒体がみられるが，その短軸は $0.2 \mu$ とほ ぼ一定であり（図35）, 円形糸粒体の、直径とほぼ一致す る. 糸粒体の数が単に増加しているだけでなく, 腫瘍細 胞によつては細胞質の 1 側に集合密在している所見が注 目される（図35，37）.粗面小胞体は系状で短く細胞質に 分散しているが，腫瘍細胞によつては核周囲に集まる傾 向がみられる. 滑面小胞体は vesicular な形態を示し， 細胞膜に接してて認められることが多い，小胞の中には bristed membrane からなる coated vesicle を認めること があるが, 正常細胞にみられるようなcompressed vesicle を涩めることはなかつた。

Lysosome は小型で円形系粒体大のものが多く，暗調 顆粒として瑟められるが，顆粒の中にはmyelin構造物を 入れるもの，あるいは筇泡化したものもみられ，系粒体 の数倍の大きさを示すものもある（図34, 35). lysosome 
顆粒は全体に増加しているが，その数は腫瘍細胞によつ て異なり，一般に表層に近い細胞に多い傾向がある.

細胞基質には、遊離 ribosome の中等度の增加がみら れ, 微細線維が発達している. 微細線維の量は第一度腫 瘍と差はない，微細線維は不定の走行を示すが，束とな ることはないままた扁平上皮にみるように desmosome と連続して tonofilament-desmosome complex を形成す ることもない，Golgi 装置は核に接して存在するが，そ の位置は不定である. 腫瘍細胞によつては vesicle の増 加による肥大，大型化した Golgi 装置を認める.

腫瘍細胞の細胞膜は互に平走し, その開離程度, およ び細胞膜から間吵への 微䄉毛突起の 発達は弱い. desmosome は小型であり数は少ない. 表層腫瘍細胞間には明 らかな tight junction 構造を認める。

3）第 3 度移行上皮癌

核の增大により核・細胞質比は一層増加し，核膜も凹 凸不整となる，ために切片上，核内偽封入物が認められ ることがある.核小体も肥大し, fibrillar component と granular component は互に複雑に入組んで nucleolonemma を示すこともあり，核内に diffuse に分散してい ることがある。また核内に perichromatin 顆粒, nuclear body などが增加していることが多い，

腫場細胞の間㔜が開き, 細胞質から多数の微䋐毛突起 を出している（図38〜40）. desmosome などの接着装置 の数は著しく減少している．細胞間隙に浸潤リンパ球の ほかに, 細胞質崩壊物 および 無定形淡調物質が 存在す る（図38）。しかし細胞と細胞を結合する tonofilamentdesmosome complex は認められない.

細胞質の 釆粒体, lysosome, 滑面小胞体, Golgi 装置 などの発達は悪く, 第 2 度癌細胞より減少する. しかし 粗面小胞体が增加していたり，大型 lysosome が出現す る. 腫瘍によつては細胞基質に著しい微細線維の增加を 示す (図42〜43).

微細線維の発達は細胞により異なり, 著しく増加して 核を輪状に取り囲んでいることがある. しかし扁平上皮 化生部分以外で微細線維が束となり tonofibrille を形成 することはなかつた．核に接する細胞質に中心小体を認 めることが多い，細胞質基質に糖原顆粒の著しい增加を 示す腫瘍細胞がみられる（図38４1）.時に細胞質に脂肪 滴や空胞を認めることがある. 第 3 度の癌細胞に明瞭な tight junction ないし big granule を観察することは出 来なかつた.

腫瘍細胞の間に暗調細胞が認められる（図39）.暗調細
胞では核，細胞質ともに濃縮するが，核質は顆粒性を失 い均質化し，核膜は強い凹凸を示し互に開いてくる．細 胞質も均質化するが，Golgi 装置，小胞体などは空泡 化する. 暗調化した細胞は隣接する腫瘍細胞との間に desmosome 結合を示し, 細胞質基質に糖原顆粒を保持 している.

第 4 度移行上皮癌（症例14）では細胞質に少数の系粒 体，小胞体を認めるほかに遊離 ribosome が充満してい て, 細胞質小器管の極端な未発達がみられ, 核・細胞質 比は著しく增加する. 細胞と細胞の結合は悪く, 接着装 置をほとんど認めることはない（図44，46）.

扁平上皮化生部の腫瘍細胞は扁平上皮癌細胞之同じ微 細構造を示している. 核質の凝集が強く, 核小体は肥 大している.核小体の granular component と fibrillar component の区別が明瞭で桑実状の nucleolonemma 構 造を明瞭に示す (図48).

細胞質には異型系粒体と粗面小胞体の発達がみられる が， その他の 細胞質小器管の 発達は弱い，細胞質基質 の微細線維は束状となり，分散することはない。この tonofibrile はしばしば desmosome と連続して周囲細胞 との間に tonofilament-desmosome complex を形成す る. 細胞間隙は増加し, 多数の微䋐毛突起を出してい る.

扁平上皮癌では核・細胞質比の大きい，核輪廓の強い 不整を示す細胞が sheet 状に配列している. lysosome, focal cytoplasmic degradation などを認めたが, keratohyalin顆粒は認められず，化生細胞と差はない(図47).

1）組織形態と悪性度

移行上皮癌の分類には第 1 度から第 4 度に分けた Broders の分類が用いられてきたが，組織形態から判定され る悪性度は正確でなく, 問題が多いことははじめに記し た。

膀脱腫瘍には多発, 再発が多いことを別にしても, 良性か悪性かの判定すら困難なことがある ${ }^{15) 16)}$. McGovern $^{17)}$ は乳頭腫の組織診が病理医により異なり, 膀腅 腫痬の中で占める割合が $2 \%$ $\% 40 \%$ 差があることは 悪性度の判定の難かしいことを物語るすのであると指摘 している. 今回の観察のよらに生検材料から悪性度を判 断しょうとする時には問題はさらに大きくなり ${ }^{12)}$, 組織 診の結果が腫瘍の真の性状を表現している訳ではないこ とに留意する必要がある. 23例の組織学的特徵をまとめ たのが表2である. 
表 2

\begin{tabular}{c|c|c|c|c|c|c|c|c}
\hline Grade & $\begin{array}{c}\text { 症例 } \\
\text { 数 }\end{array}$ & 非乳頭 & 糖原 & $\begin{array}{c}\mathrm{B} \mathrm{G} \\
\text { 細胞 }\end{array}$ & $\begin{array}{c}\text { 偽腺㥞扁平上 } \\
\text { 変化 }\end{array}$ & 脱落 \\
\hline I & 2 & $0 / 2$ & $1 / 2$ & $1 / 2$ & $1 / 2$ & $0 / 2$ & $0 / 2$ \\
\hline II & 10 & $1 / 10$ & $7 / 10$ & $5 / 10$ & $7 / 10$ & $0 / 10$ & $2 / 10$ \\
\hline II & 11 & $9 / 11$ & $6 / 11$ & $1 / 11$ & $2 / 11$ & $6 / 11$ & $11 / 11$ \\
\hline 計 & 23 & $10 / 23$ & $14 / 23$ & $7 / 23$ & $10 / 23$ & $6 / 23$ & $13 / 23$ \\
\hline
\end{tabular}

B G 細胞：巨大顆粒を有する表層腫煬細胞

肉眼上乳頭状発育を示した腫瘍は 13 例あり，いずれも 第 1 度ないし第 2 度の分化型癌であつた. 非乳頭腫瘍は 10例あり，その 9 例は第 3 度癌であつた．分化型で非乳 頭状発育を示した腫瘍は 1 例にすぎない，乳頭性か非乳 頭性かといらことは分化型, 未分化型癌の肉眼的判定上 重要である.

腫瘍細胞内に糖原は14例60\%に認められ，予期以上に 多いことを知つた．しかし悪性度との関係では第 2 度腫 瘍 $(70 \%)$ と第 3 度腫瘍 $(54 \%)$ と大きい差はなく，糖 原の有無は腫瘍の悪性度と関係がないように思われた。 他蔵器に発生した扁平上皮癌に糖原を証明することはま れであるのに対して ${ }^{18)}$ ，糖原陽性の移行上皮癌に打ける 扁平上皮化生部が糖原陽性であることが注目された。

巨大顆粒を有する表層細胞は分化型癌で 6 例 (50\%) であるのに第 3 度癌では 1 例しかみられず，この表層細 胞の有無は移行上皮癌の分化度を示すものと思われた. この表層細胞の有無は後述するように tight junction の 有無を反映し，腫瘍表面の偽腺様変化と密接な関係があ る. しかも分化型腫瘍では正常上皮と同じく最表層細胞 にのみ巨大顆粒を認めるのに対して，未分化癌の 1 例に は深部の腫瘍細胞にも認められた。 このことから分化型 では基底細胞から表層細胞への成熟過程を示し，脱分化 の程度が少ないことを，換言すれば正常からの扁倚の小 さいことを示している．同時に分化型ではtight junction が存在し，腫瘍細胞の脱落が少ないのに，未分化型では tight junction の発達を欠き, 腫瘍細胞の脱落がみられ ることを示している.

腺様化生は分化型で 8 例認めたが，第 3 度では 2 例に すぎない，そして偽腺様变化を示す注とんどの症例（70 \%) に巨大顆粒を有する表層細胞を認めた，腺様化生は 表層細胞が tight junction などによる強固な結合で脱落 することなく，下部腫瘍細胞の增生が一様でないために
腫瘍表面の乱れによつて生ずると思われる．時に間胿に PAS 陽性物質の充満をみるが，これは Brunn's nest の 中心部細胞が示す変化と同様であつて ${ }^{12) 199}$, 膀胱腔との 交通を断たれた間隙に対面する移行上皮細胞の変化と思 われる．偽腺様変化は分化型移行上皮癌に多く認められ る変化であつて, 腫瘍性異分化 (disdifferentiation) の表 現である扁平上皮化生ないし腺上皮化生と同一視するこ とは出来ない.

腫瘍表面からの腫瘍細胞の脱落程度は表層細胞の存在 および偽腺様変化とは反対に未分化型で強い，第 3 度癌 では全例に脱落所見を認めたが，分化型では 2 例にすぎ ない.腫瘍細胞の脱落の程度および有無は移行上皮癌の 悪性度の判定に重要である. 多発する膀朕腫瘍が多中心 性に発生するのか, 脱落腫瘍細胞が粘膜に接種されて発 生するかについては議論があり決定されていない2220). かりに後者とすれば脱落の有無は腫瘍の多発および再発 に重要な役割を演じていることになる．そして今回の観 察では第 2 度移行上皮癌の中で 2 例が脱落を示し， 8 例 に脱落所見は認められなかつたが，同一の分化度を示す 腫瘍でも脱落の有無による subclassification が可能であ ると考兄れる.

扁平上皮化生は扁平上皮癌の 1 例を除いて第 3 度移行 上皮癌の 5 例にみられた．分化型では全くみられず，扁 平上皮化生の存在は悪性度の高いことを示す指標となつ ている. 膀胱腫瘍の悪性度は膀胱壁に対する浸潤度によ つて規定されるから，後述するよらに移行上皮と扁平上 皮では增殖方向を異にすると考兄られるから，扁平化生 を伴う腫瑒がより強い浸潤性を示すことは当然である.

2）移行上皮癌の增殖方向

乳頭性が非乳頭性かといら性質は腫瘍の分化度と密度 な関係を示す．乳頭性增生に関して石川 ${ }^{21)}$ は urothelium の增殖方向が扁平上皮と異なることによると考えてい る. 移行上皮では遊離面に対して平行方向に増生する。 この特性は腫瘍も発揮する故に, 腫瘍の発育は主として 側方に進み，粘膜は伸展し回転形成して乳頭䄉毛腫瘍を 形成するといい，扁平上皮のように基底膜の垂直方向の 增生は弱いという。 Leblond and Walker ${ }^{11)}$ は移行上皮 粘膜では基底細胞と同じく表層細胞にも分裂能が認めら れ，基底細胞だけが分裂能を示す扁平上皮と異なること を明かにしている。これにたいし Martin ${ }^{2324)}$ は移行上 皮でも基底細胞だけに分裂能が認められるという。

腫瘍の悪性度の判定には核分裂の頻度が重要な指標と なるが，同時に核分裂のみられる部位の観察から增殖方 
向を知ることが出来る. Fulker ら ${ }^{25}$ は分化型移行上皮 癌の mitotic index は腫瘍細胞1000個当り 1.3 , 未分化 型では 4.8, anaplastic tumor では13.1であり, 腫瘍の 表層部と基底部とで差はないという．Battifora ら ${ }^{26)}$ ${ }^{3} \mathrm{H}$-thymidine による腫瘍細胞のラベル率は正常粘膜で $0.3 \%$ であるが，移行上皮癌の第 1 度では $1.7 \%$, 第 2

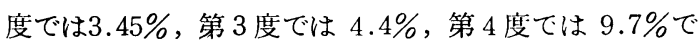
あり，悪性度との相関を示しているといら．ラベル率の 場合には腫瘍細胞の DNA 合成期の延閔, doubling time の短縮を考虑する必要があり, mitotic index と一致し ないことがあるという。

松村 ${ }^{27)}$ は thymidine により腫瘍の增生部位が腫瘍の分 化度によつて変化することを明かにしている. 正常粘膜 では thymidine ラベル細胞は基底細胞にみられるのに対 して, 乳頭腫では基底層と中間層の一部にみられ，多発 腫瘍および初期癌では中間層が主たる増生部位であると いう. そして浸潤癌になつて始めて基底層, 中間層, 表 層の全層にわたる增生がみられるという．このように腫 瘍の增生位置が腫瘍の分化度によつて異なることは腫瘍 の増殖方向を規定している可能性を示唆する.

中間層を主たる增生部とする分化型移行上皮癌では側 方方向への増生を主とし浸潤傾向は弱いのに対して, 全 層が增生部位である未分化型では垂直方向への増殖を示 すが故に浸潤性になりやすいと考えることが出来る.こ のことは正常粘膜の示す基底細胞から表層細胞への段栺 的成熟過程を維持しているか否か，すなわち腫瘍の示す 脱分化の程度を反映するとも考兄られる．増生方向を異 にする扁平上皮の特性を示す扁平上皮癖ない儿扁平上皮 化生部を示す移行上皮癌が強い浸潤性を示し，悪性度が より高いと判定されることはこの点からよく理解され る.

腫瘍の增殖方向に関して注目されるのは Golgi 装置の 位置である. $\operatorname{Koss}^{28)}$ は正常移行上皮細胞では Golgi 装 置に一定の極性がみられるという．すなわち基底細胞で Golgi 装置は核の側方に位置し，中間細胞では核の上方 すなわち表面側に, 表面細胞では核の下方すなわち基底 側に位置するという。しふし今回の観察では腫湟分化度 とは関係なく, 腫塂細胞の中で占める Golgi 装置の核に 対する位置は全く不定であり，一定の極性は認められ ナ゙, Golgi 装置から腫瘍の增殖方向を推測することは蚔 来なかつだ.な技 Koss は Golgi 装置の位置から判断し て中間細胞から表面細胞への成熟過程で $180^{\circ}$ pivot す ると考えているが，隣接細胞との問に多数の接着装置を もつた上皮細胞が回転するとは考学がたく，Golgi 装置
自体が移動すると考えるべきであろう，細胞の機能変化 に応じて Golgi 装置が移動することが肝細胞 ${ }^{29}$ などで認 められているからである.

3）腫瘍と化生

移行上皮は扁平上皮と 円柱上皮との中間的構造を示 す上皮としてその名がある. Melicow ${ }^{4)}$ は移行上皮は water-proof である点で扁平上皮と異なり，収縮伸展に 適した棈造に分化した上皮である故に基底膜はみられな いと報告している．その後移行上皮が基底膜を有するこ とは電顕的汇証明された ${ }^{30) ~ 32) . ~ A e d e r s o n ~}{ }^{10)}$ は移行上皮 は分化の程度の低い扁平上皮であるとし, 移行上皮の扁 平上皮化生は分化の進行を意味し，真の意味での化生と 区別すべきで protoplasiaといらべきであり，移行上皮の 真の化生は腺化生であるという． Hichs ${ }^{9}$ は移行上皮自体 が角化上皮としての性状を備えているという．Gordon ${ }^{8)}$ は膀腅粘膜の腸上皮化生と arggentaffine 細胞, Paneth 細胞などの出現に言及している.

膀脱粘腺は他組織よりも高頻度に慢性刺激によつて腺 上皮化生，扁平上皮化生を示す，それは腺性膀脱炎， Brunn nest, leukoplakia などとして知られている33334. 先に述べたように腫滸には異分化, 脱分化がみられるか $5^{60)(1)}$, 移行上皮腫瘍においては正常組織よりも化生を 示すのは容易であると思われ, 移行上皮腫瘍が高い頻度 で腺上皮ないし扁平上皮化生部を含むことは理解され る.腺化生については腫瘍細胞の变性により生ずる変性 空胞, 偽腺様変化と区別する必要がある.

扁平上皮化生 : 移行上皮癌の一部の扁平上皮化生は光 頙的には細胞間橋, 腫瘍細胞の角化, 癌真珠の存在によ つて確認されるが, 超微構造上は tonofibrile, tonofilament-desmosome complex の発達, keratohyalin 顆粒の存 在, desmosome 結合の増加などにより確認される ${ }^{18}$. したがつて化生を組織的検索では示さない膀腅腫瘍に 電顕的検索で始めて扁平上皮化生が認められる場合があ る. 光影的検索では角化傾向を伴わない化生を確認する ことは必ずしも容易ではない，そのことは同時に移行上 皮と扁平上皮の近縁性として理解される.

今回の観察では光顕的並びに電顕的検索により第 3 度 移行上皮癌 9 例中 5 例に部分的扁平上皮化生を認めた. こ机は約55\%となるが，Dean 5 ${ }^{35}$ の非乳頭性腫瘍の 41 \%といら高率で扁平化生部分がみられるといら報告と一 致している. 今回の観察でも第 2 度以下の分化型腫湟に は 1 例も扁平上皮化生は認められていない. 同じ未分化 型であつても扁平上皮化生を伴う腫瘍は扁平上皮化生を 
伴わない腫怚よりる悪性度は高いものとして扱われるべ きであると考劣る. 電顕的に角化腫瘍細胞を観察するこ とができなかつたが，膀胱原発の扁平上皮癌と移行上皮 癌の扁平上皮化生部との間の腫瘍細胞の間に本質的差を 見出すことは出来なかつた。

4）腺上皮化生

Urotheliumの性質から考光て移行上皮癌の部分的腺化 生も扁平上皮化生同様多いものと考兄られるが，今回の 観察では变性空胞, 偽腺椂变化は多くみられたが, 真の 腺上皮化生は第 3 度の腫瘍 1 例に認められたにすぎな い. 腫瘍全体が腺癌であつた例は 1 例もなかつた，先に 述べたよらに変性空胞, 偽腺様変化は分化型腫湯に多く みられ，悪性度の上昇を示す所見ではなく，真の意味で の腺上皮化生と区別しなければならない，腫瘍表面の偽 腺様変化を腺癌と同一視することは誤りである ${ }^{37)}$. 同様 䏽胱原発の腺癌をすべてurachal originとみなすことも 誤りであり，移行上皮由来の腺癌が存在することに留意 する必要がある. Thomas $ら^{36)}$ は膀胱腺癌52例を報告し ているが，頂部に発生した urachal 腺癌は24例であり， 膀胼底部括よび尿管部から発生した化生性腺癌が28例で urachal 腺癌の方が少ないと報告している. Evans ${ }^{12)} は$ 直腸癌と似た組織形態を示す腺癌が膀胱に原発すること があり，これは膀脂粘膜と直腸粘膜が発生学的に cloaca といら共通原基から発生する事と関係があるかも知れな いと述べている.

5）表層腫瘍細胞の tight junction と巨大顆粒

今回の観察では分化型腫瘍の表層細胞間に tight junction 構造を認めたが, 未分化腫湯に tight junction 構造 は認められなかつた。るつとも電顕的検索では腫湯の一 部分しか観察できず, small sampling method であり, 各例で tight junction の有無を正確に決定することは困 難であつた。 未分化腫瘍 では tight junction のみなら ず, desmosome などの細胞間の 接着装置はすべて著明 な減少傾向を示していた. この tight junction を含めて の接着装置の減少は腫瘍の分化度の低下すなわち昰性度: の上昇と比例して強くなるように思われた，未分化腫瘍 に tight junction が認められなくなることは Fulker ら ${ }^{25)}$ も報告している.

先に述べた偽腺様変化, 表層細胞の存在, 变性空胞な そは tight junction 構造の分化を示す腫場にみられ，腫 瑝細胞の脱落, 粘膜固有層の変化などは tight junction 構造の分化を欠く腫瘍ないし腫湯部分に出現すると考之 られるから，移行上皮癌が tight junction 構造を有する
か否かは腫瘍の組織形態および悪性度に大きな影響を及 洔すことになる。また tight junction を欠く腫煌では尿 成分の腫瘍内渗透が容易となり dark cell の出現にも関 係することになると考える.

組織的に同定される表層細胞の PAS 陽性粗大顆粒を 含む空胞は微細構造上一枚の限界膜に团まれ, 種々の暗 調物質を含むが一種の lysosome として認められる.こ のことは $\mathrm{Koss}^{28)}, \mathrm{Hicks}^{38)}$ らも報告していて, 正常粘膜 では表面細胞だけが有する構造物であり，Fulker ら ${ }^{25)}$ は large telolysosome として報告している. この構造物 について著者らは先に報告したが ${ }^{13)}$, 電顕的に正常粘膜 および腫瘍に多くの人により確認されているが，その機 能については不明の点が少なくない(25)28)31) 333 39) 42). こ の巨大顆粒は分化型腫腸に認められることが多いが，未 分化型腫瘍には認められない：これは表層細胞の脱落の ほかに未分化腫瘍における表層腫揚細胞の分化の衰失を も意味する.一方, 腫瘍では深部細胞まで lysosome 顆 粒の增加が注目された。

生化学的に urothelium ${ }^{\prime}$ alkaline phosphatase, acid phosphataseを含むことが知られている. 石部ら ${ }^{43)(4)}$ は膀 胱腫瘍で解糖に関係する lactic dehydrogenase, alkaline phosphatase, acid phosphatase が增加するといい，未 分化腫瘍では lactic dehydrogenase は低下するという. Vacek ${ }^{45)}$ らは巨大顆粒の增加につれて alkaline phosphatase は減少し, non-specic esterase は増加するという. また一方膀胱癌の発癌過程で $\beta$-glucronidase の上昇が注 目されている ${ }^{47)}$. これら膀胱粘膜および膀胼腫湟の示す 生化学的特徽の中の acid phosphatase, $\beta$-glucronidase, non-speciffc esterase などの lysosomal enzyme の変動は 形態的に巨大顆粒ないし lysosome 顆粒の変動として把 握さるれから，腫煬細胞の lysosome の推移に注目する ことが必要である.

6）暗調細胞と固有層および間質変化

暗調細胞の出現は腫瘍表面の脱落所見を強く認める症 例にみられたことから，尿の腫瘍内渗透と関係があると 思われた．尿中の毒性物質による腫韵細胞の変性像之考 えられる. 電顕的にも核, 細胞質に高度の濃縮変性を認 めることが出来た. しかし障害因子の有無とは無関係に 未分化癌では暗調細胞と淡明細胞の混在が認められるか ら，腫瘍の特徵的性質による暗調細胞の出現も考虑する 必要がある1418). いずれにして子暗調細胞の多数の出現 は悪性度の上昇を示す所見と考えられる。

尰瘍間質および粘膜固有層にはリンパ管，血管の拻 
張, 浮腫,リンパ球, 形質細胞の浸潤などがみられた。 $\mathrm{Sarma}^{48)}$ は移行上皮癌の間質に単なるリンパ球浸潤のほ かにリンパ濾胞の形成がみられることがあるといい，一 般に未分化腫瘍ではリンパ球反応は弱く, 分化型腫瘍で 強い反応がみられるという．また鈴木ら ${ }^{49}$ 女分化型腫瘍 でリンパ球反応が強くみられることから，間質および固 有層のリンパ球反応は個体の示す腫崵免度ないし防禦的 反応であると考㐫ている. しかし今回の観察では間質変 化は種々であり，一定の傾向を認めることは出来なかつ た.しいて言えば腫瘍細胞の脱落, 暗調細胞の出現を示 す分化型腫湯症例に間質変化が強い傾向があり, 暗調細 胞と同じく，間質変化は尿成分の渗透と関係するように 思われた。

7）腫瘍細胞の細胞質小器管

Compressed vesicle: 移行上皮の表層細胞および中間細 胞の一部が unit membrane からなる特異的小胞 compressed vesicleを有することが知られている

Walker ${ }^{31}$ は throtrast が表層細胞の pinocytotic vesicle に入るが, compressed vesicle に取り込まれないことか ら，これは水分の吸収に関係する構造物と考えて報告し たが，現在では膀胱の収縮他緩に関与する構造物であ り, 膀脱伸展時の予備細胞膜であることが 知られてい

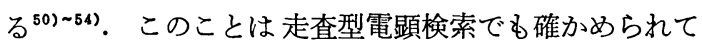
いるし ${ }^{58)}$, Hicks ${ }^{9}$ は通常の細胞膜より compressed vesicle 膜がより厚いことから keratin 物質を含むことを指摘 乙，移行上皮が water proof である性質は compressed vesicle 膜の性質によるという. Fulker $2^{25)}$ 分化型移行 上皮腫瘍細胞に小数の compressed vesicle を認めるとい 5. しかし今回の観察では腫湯細胞にpinocytotic vesicle および coated vesicle を認めることはあつたが，分化度 の如何を間わず， compressed vesicle を認めることはな かつた. 畽瘍細胞が収縮弛緩という運動性を有すること はないと思われるから， compressed vesicle を欠くこと は当然であろう.かりに Fulker ら ${ }^{25)}$ の報告のように分 化型腫場細胞が compressed vesicleを有するとしても, それは腫瘍細胞の運動能を意味するるのではなく，正常 細胞の成熟分化の遺残を分化型腫瘍細胞が示していると 解釈すべきであろう.

Golgi 装置：移行上皮細胞の Golgi 装置の機能は膜成 分の産生部ないしその $\operatorname{depot}^{28) 54)}$, 表面細胞では compressed vesicle の 産生部位 ${ }^{38)}$ 考えられている. しかし Golgi 装置は細胞質物質運搬の中枢でもあるから，移行 上皮が分泌ないし吸収という特殊機能を有していて，そ
れと関係した機能, lysosome 産生部位としての機能など が考兄られる. 腫瘍細胞では一般に細胞質小器管は減少 するが, Golgi 装置は肥大していることが多かつた， の傾向はとくに分化型腫湟で強くみられた. Compressed vesicle の発達を欠く腫瘍細胞の Golgi 装置の機能は正 常と異なる筈であるが，肥大の意義は不明である．単に 腫場細胞の代謝活性がえ進していることを示しているの かも知れない.

膀胀粘膜が糖原を含有していることが知られてい

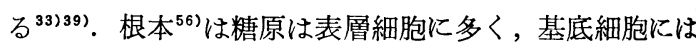
みられないことが多いといらが，Monis ら ${ }^{57}$ は移行上皮 の全層に認められるといら．正常細胞の機能により糖原 量は変動するのであろう. 糖原は光顕的に diastase で消 失する PAS 陽性微細顆粒として細胞質にみられるが, 電顕的には水酸化鉛飞染る黒色微細粒子として認められ る. 䔟行上皮腫瘍に糖原が認められることは Fulker ${ }^{25)}$, Flacks $^{30)}$ らも電顕的に証明している. 今回の観察では腫 瘍細胞糖原陽性例と陰性例がみられたが，糖原の有無と 腫瘍の分化度とは無関係であり, 腫湟の糖原有無の生物 学的意義は不明である. Kretschmer ら ${ }^{59}$ は淡明細胞集 団を腫瘍の部分的変性巣と考えているが, 糖原蓄積巣で あり誤りであると思われた，暗調腫瘍細胞にも糖原が認 められることから, 正常と異なり腫瘍細胞の糖原は細胞 機能により変動する事は少ないと思われる.このことが 腫愓細胞の解糖に関与する酵素作用の欠損を意味するか 否かは残された問題である.

8）分化移行上皮癌細胞の電顕的特徵

Fulker ${ }^{25)}$ らは腫煬細胞によつて 構造に差があり多彩 となるが，一般には系粒体，Golgi 装置，小胞体などの 細胞質小器管は减少し, 細胞構造は単純化するという. そして, 表層腫瘍細胞は tight junction がみられるが， compressed vesicle は著しく減少するという.この腫煬 細胞の構造単純化は腫瘍脱分化の表現であつて, 細胞代 謝活性の減少を意味するものではないという，今回の検 索では compressed vesicle が認められない点で異なり, 症例によつて糸粒体, Golgi 装置, lysosome などの細胞 質小器管の減少傾向が認められたが，症例によつてはか えつて增加している事があり注目された. しかも細胞の 1 側に系粒体を主とする小器管の集合密在所見が注目さ れた. 正常細胞では細胞質小器管は内腔側に集まる傾向 があり, 柏井 (4)は分化型で表層側細胞質に小器管が集ま るといらことは極性の保持として分化型腫瘍細胞の特性 として強調している.しかし，今回の観察ではこの集合 
密在部は必ずしも腫瘍表面に向ら細胞質ではなく，at random であることが注目された. しかし未分化型でか かる所見は認められず，一種の極性の遺残所見として注 目された。

Battifor $^{26)}$ らは腫瘍細胞間の 間隚が 増加すること, dark cell が増加することを指摘しているし, Flacks ら は正常細胞に比し核・細胞質比, 核小体が増大し, 遊離 ribosome, lysosome, 細胞基質の微細線維, 細胞間吵に向 ら微䋐毛などが増加し, 糖原顆粒, Golgi 装置などは減 少ないし縮少するという. 一方系粒体, 粗面小胞体の量 は不変であるが, 糸粒体の異常 crista の出現, crista の 減少，粗面小胞体の脱顆粒などが增加するという．なお Flacks ${ }^{30}$ は限界膜をもたない branched coral 様構造物 すなわち, ribosome 顆粒の異常凝集物を分化型腫演細 胞に認め, ribonuclear body として報告している.これ らの結果は著者らの検索所見と似ているが, ribonuclear body は認められなかつた.

9）未分化移行上皮癌細胞の電顕的特徵

Batlifora $^{26)}$ は末分化癌細胞に 核輪廓の不整, 核・細 胞質比の 增大, cytolysosome の增加, 細胞基質の遊離 ribosome の增加などがみられ, Fulkerら ${ }^{25)}$ は compressed vesicle, tight junction 構造が認められなくなることを 報告している.これらは今回の検索でも観察された変化 である.な抢，Batlifora は小胞体の層状ないし輪状配 列を報告し, Fulker ${ }^{25)}$, Flacks ${ }^{30)}$ らは crista が瀜巻状な いし同心円状配列を呈する異型糸粒体が増加するといら が，今回の検索では系粒体の異型は扁平上皮化生部およ び扁平上皮癌細胞に認めたが, 移行上皮癌細胞には認め られなかつた. 一方 Golgi 装置について Fulker らは肥 大するといい, Flaks は萎縮するといらが，著者らは Golgi 装置の肥大傾向を認めた. 粗面小胞体は未分化細 胞で扗張と脱顆粒を強く示すといらが30)，今回の検索で 粗面小胞体の強い変化をみることはなかつた. 今回の結 果では未分化腫湯細胞の電顕特徵は細胞間接着装置の著 しい減少にあると思われた.すなわち tight junctionを 亦失し, desmosome は減少し, かつ小型化する.そして 属場細胞の間隙に細胞質から微䋐毛栏突起を多数出す变 化がみられたのである.この変化は症例によつて多少異 なるが, 悪性度の增加につれて強くなるように思われた。

一方, 細胞質の采粒体, 小胞体, Golgi 装置などの発 達は悪性度の增加につれて悪くなり, 代つて細胞質基質 の遊離 ribosome が増加する.ただし細胞質基質の微細 線維の量は症例によつて異なり，末分化腫瘍でも強い発
達を示すことがあり，悪性度とは相関しないように思わ れた。

柏井 ${ }^{14)}$ は dark cell の出現が悪性度の上昇を意味し, 悪性度の高い例に多数出現するといらが, 今回の検索で は dark cell の出現は悪性度の上昇を示す直接的本質的 変化ではなく, 腫瘍細胞の示す二次的变性像であると考 えられた.

\section{むすび}

経尿道的に生検された移行上皮癌23例を組織学的なら びに電顕的に観察し, 腫瘍細胞の構造と分化度の関係に 焦点を置いて検索考按した結果を報告した。

移行上皮癌の純形態学的分類には問題が多く, とくに 第 1 度と第 2 度の分類に意義は少なく, 分化型移行上皮 癌と一括されるべきであると思われた．分化型腫瘍は乳 頭発育を示し, 通常の組織異型とは別個に, 腫瘍表面の 偽腺様変化, 腫瘍細胞の変性による变性空胞, 巨大顆粒 をもつた表層腫瘍細胞の存在, 電顕的糸粒体の增加と集 合傾向, tight junction の存在などが分化型移行上皮癌 の特徵的所見として注目され，一方未分化移行上皮癌で は扁平上皮化生, 腺上皮化生, 腫瘍細胞の脱落, 暗調細 胞の増加, 電顕的には各種細胞質小器管, 細胞間接着装 置の減少, 表面微䋐毛様突起, 遊離 ribosome の增加が 注目された. 細胞質基質の glycogen 顆粒の有無, 微細 線維の発達程度は腫瘍分化度とは無関係のように思われ た. 扁平上皮化生は未分化腫湯にみられ，電顕的には tonofibrile, tonofilament-desmosome complex などの增 加および desmosome の増加として認められた.

な敃移行上皮癌の增殖方向，腫瘍間質反応などについ ても言及した。

（最後に御指導と御校閲していたたいた北海道大学泌 尿器科学教室辻一郎教授に深謝します)

本研究は昭和 $44,45,46$ 年度厚生省が ん研究助成金 （班長市川篤二東大名誉教授）の援助を受けたものであ る.

\section{文献}

1) Broders, A.C.: Ann. Surg. 75, 574, 1922.

2）笠松エレナ, 三谷玄悟, 山田 喬, 癌の臨床, 17, 719, 1971.

3) Jewett, H.J., King, L.R. and Shelley, W.M.: J. Urol., 92, 668, 1964.

4) Melicow, M.M.: J. Urol., 54, 186, 1945.

5) Maluf, N.S.R.: J. Urol., 69, 396, 1953.

6) Rapaport, A., Nicholson, I.F. and Yeudt, E.R.: Am. J. Physiol., 198, 191, 1960. 
7) 根本万次：日本組織学紀録，5,355，1953.

8) Gordon, A.: J. Path. Bact., 85, 441, 1963.

9) Hicks, R.M.: J. Cell Biol., 28, 21, 1966.

10) Anderson, C.K.: Proc. R. Soc. Med., 48, 699, 1955.

11) Mostofi, F.K. and Leestma, J.E.: in Pathology ed. W.A.D. Anderson, Mosby Co. St. Louis, 1971.

12) Evans, R.W.: Livingstone, 1968.

13）小野江為則，布施裕輔：日癌，23回記事，345, 1956.

14) 柏井浩二：日泌尿会誌, 52, 908，1961.

15) Dean, A.L. et al.: J. Urol., 71, 571, 1954.

16) Friedman, N.B. and Ash, J.E.: A.F.I.P. Section VIII, Fascicle 31 a, p. 50, Washington, D.C., 1959.

17) McGovern, V.J.: Pathology, 1, 255, 1969.

18）浅川三男，布施裕輔：札幌医誌 (印刷中).

19) von Brunn, A.: 文献 12）ょり引用

20) 市川篤二, 石山修二, 辻一郎: 日新医学, 42 , 201, 1955.

21) 石川栄世：臨床組織病理学, 杏林書院, 1967.

22) Leblond, C.P. and Walker, B.E.: Physiological Review, 36, 255, 1971.

23) Martin, B.F.: J. Anat., 109, 351, 1971.

24) Martin, B.F.: J. Anat., 112, 433, 1972.

25) Fulker, M.J., Cooper, E.H. and Tanaka, T.: Cancer, 27, 71, 1971.

26) Battifora, H.A., Eisenstein, R.; Sky-Peck, M.M. and McDonald, J.H.: J. Urol., 93, 217, 1965.

27) 松村陽右: 泌尿器科紀要, 13, 185, 1967.

28) Koss, L.G.: Lab. Invest., 21, 158, 1969.

29) Fuse, Y. Sapporo Med. J., 35, 135, 1969.

30) Flaks, B., Cooper, E.H. and Knowles, J.C.: Europ. J. Cancer, 6, 145, 1970.

31) Walker, B.E.: J. Ultrastruct. Res., 3, 345, 1960.

32) Leeson, C.R.: Acta Anat., 48, 297, 1962.

33) Göldi, K.: Z. Mikr-Anat. Forsch., 58, 256, 1952.

34) Patch, F.S. and Rhea, L.J.: Canad. M.A.J., 33, 597, 1935.

35) Dean, A.L., Mostofi, F.K., Thomas, R.V. and Clark, M.L.: J. Urol., 71, 571, 1954.
36) Thomas, D.G., Ward, A.M. and Williams, J.L.: Brit. J. Urol., 43, 4, 1971.

37) Rosas-Uribe, A. and Luna, M.: Arch. Path. 88, 294, 1969.

38) Hicks, R.H.: J. Cell Biol., 30, 623, 1966.

39) Mende, T.J. and Chambers, E.L.: J. Histochem. Cytochem., 5, 99, 1957.

40) Hicks, R.M. and Keterer, B.: Nature, 224, 1304, 1969.

41) Battifora, H., Eisenstein, R. and McDonald, J.H.: Invest. Urol., 1, 354, 1964.

42) 飯田 収：日泌尿会誌, 55, 333，1964.

43) 石部知行, 仁平寬已: 泌尿器科紀要, 16, 3, 1970.

44) 石部知行, 仁平宽已: 泌尿器科紀要, 16,68 , 1970.

45) Vacek, Z. and Schuck, O.: Anat. Rec., 136, 87, 1960.

46) Mostofi, F.K. and Leestma, J.E.: in Pathology Sixth ed. Anderosn, W.A.D. Mosby, 1971.

47) 森 侑, 斉藤 薫, 多田 茂: 日泌尿会誌, 60 , $874,1969$.

48) Sarma, K.P.: J. Urol., 104, 843, 1970.

49) 鈴木騏一, 加藤正和, 小野寺豊, 菅原奎二, 宮 田宏洋, 黒沢昌也：日泌尿会誌, 60, 881, 1969.

50) Wolf, J.: Folia Morphol., 14, 17, 1966.

51) Richter, W.R. and Moize, S.M.: J. Ultrastruct, Res., 9, 1, 1963.

52) Porter, K.R., Kenyon, K. and Badenhausen, S.: Protoplasma, 63, 262, 1967.

53) Petry, G. and Amon, H.: Z. Zellforsch., 69, 587, 1966.

54) Grove, S.N., Bracker, C.E. and Moore, D.J.: Science, 161, 171, 1968.

55) Ferguson, D.R. and Heap, P.F.: $Z$. Zellforsch., 109, 297, 1970.

56) 根本万次：日本組織学舐録，5,77，1953.

57) Monis, B. and Dorfman, H.D.: J. Histochem. Cytochem., 15, 475, 1965.

58) 收口 弘, 他 : 医学のあゆみ, 75, 127, 1970.

59) Kretschmer, H.L. et al.: J. Urol., 36, 651, 1936.

60) Onoe, T. and Fuse, Y.: Tumor Res., 1, 143, 1966.

61) Fuse, Y. Tumor Res., 4, 1, 1969.

（1973年 4 月 23日受付） 